\title{
Kandinsky's fragile art: a multidisciplinary investigation of four early reverse glass paintings (1911-1914) by Wassily Kandinsky
}

\author{
Simon Steger ${ }^{1 *} \mathbb{D}$, Diana Oesterle ${ }^{2,3}$, Simone Bretz $^{4}$, Lisa Frenze ${ }^{5}$, Heike Stege ${ }^{6}$, Iris Winkelmeyer ${ }^{5}$, Oliver Hahn ${ }^{1,7}$
} and Gisela Geiger ${ }^{2}$

\begin{abstract}
This work highlights the rediscovery of the technique of reverse glass painting by the artists of the "Blaue Reiter" collective in the early 20th-century and focusses particularly on the role of Wassily Kandinsky (1866-1944). Kandinsky created more than 70 reverse paintings on glass and showed several of them in exhibitions together with paintings on canvas and cardboard, implying a coequal importance of these techniques. Four of his early (1911-1914) reverse glass paintings (Auferstehung, Allerheiligen II, Rudern, Apokalyptischer Reiter II) were selected for investigation and their iconography, painting techniques and painting materials were examined. Two paintings were executed on so-called cathedral glass, revealing a "hammered surface", whereas Kandinsky used a corrugated glass panel for Rudern. A multi-analytical, non-invasive approach [X-ray fluorescence (XRF), diffuse reflectance infrared Fourier transform spectroscopy (DRIFTS), VIS spectroscopy (VIS), Raman spectroscopy] was taken to identify the pigments and classify the binding media. The results reveal a broad palette of materials. Several pigments like lead white, zinc white, strontium yellow, Prussian blue, viridian, cadmium yellow, ultramarine blue, cinnabar and carbon black were found in most of the four paintings. The use of the rare synthetic organic pigments PR60 and PB52 is discussed. In two works of art, cadmium carbonate is associated with cadmium yellow. The identification of aluminium foil along with tin foils in Rudern indicates an early use of this material for reverse glass paintings.
\end{abstract}

Keywords: Kandinsky, Reverse glass painting, Non-invasive analysis, Pigment identification, DRIFTS, Synthetic organic pigment, Cadmium carbonate, Aluminium foil

\section{Introduction}

In the past, the technique of reverse glass paintings was often considered to be part of the stained glass genre; however, in contrast to stained glass, reverse glass paintings are viewed in reflected light and their creation does not involve a firing step. The paint layers are, compared with paintings on canvas, applied in reverse succession, starting with the front most layer and ending with the backing layer. Little art-historical research has been done on this technique and especially its importance for 20thcentury art is poorly understood. The mass production

\footnotetext{
${ }^{*}$ Correspondence: simon.steger@bam.de

${ }^{1}$ Federal Institute for Materials Research and Testing (BAM), Division 4.5,

Unter den Eichen 44-46, Berlin, Germany

Full list of author information is available at the end of the article
}

of folkloristic reverse glass paintings in the 19th-century created a rather undervalued image of this technique in art history. A very limited number of scientific studies on reverse glass paintings have been published. Several publications deal with 14th to 19th-century reverse glass paintings including sampling of the objects [1-4]. Transportation and sampling of paintings is often restricted due to the fragility of the glass support, hence non-invasive methods have been carried out to collect information on the materials [5, 6]. Recently, non-invasive analyses of 20th-century reverse glass paintings has been published [7-9]. A publication on Chinese reverse glass paintings from the 19th-century discusses a possible influence of these paintings on European 20th-century reverse glass painting from the "Blaue Reiter" collective [10]. 
This paper will highlight the rediscovery of the technique of reverse glass painting by the artists of the "Blaue Reiter" collective in the early 20th-century and in particular will shed light on the role of Wassily Kandinsky (1866-1944). Four of his early reverse glass paintings (Auferstehung, 1911, Allerheiligen II 1911, Rudern, c. 1912, Apokalyptischer Reiter II, 1914) were selected and their iconography, painting technique and painting materials were examined. The main objectives of this study are: (1) to work out the starting date of modern reverse glass paintings (2) to discuss the importance of this technique for Kandinsky's oeuvre, (3) to examine the painting technique, (4) to highlight the influence of folkloristic 19th-century reverse glass paintings from Bavaria, and (5) to conduct non-invasive, in situ spectroscopic analyses to identify the colourants and classify the binders.

\section{Art historical context}

Folkloristic art was an important source of inspiration for Wassily Kandinsky, Gabriele Münter (1877-1962) and their colleagues from the "Blaue Reiter" collective. In September/October 1908, Kandinsky and Münter together with their friends Marianne von Werefkin (1860-1938) and Alexej Jawlensky (1864-1941), spent their first summer stay in Murnau near Munich. The four artists came back next year in the summer of 1909, enjoying the natural surroundings and the quiet life in this small village. Until 1914, Kandinsky and Münter lived not only in Munich, but also spent several months every year in Murnau, where Münter bought a small villa.

Murnau, Seehausen and Uffing am Staffelsee were the main sites of folkloristic reverse glass painting tradition, a technique that started to disappear at the turn of the century. Generally, Münter states that this technique was new to their entire group and that they first came in touch with it in Murnau. Moreover, it was Jawlensky who introduced them to the local master brewer Johann Krötz and to the artist Heinrich Rambold (1872-1955) [11, 12]. The private collection of Krötz included numerous traditional Bavarian reverse glass paintings, which were important sources of inspiration for the artists. Kandinsky, Münter and Jawlensky started to build up their own collection of European and non-European reverse glass paintings, which they used to decorate their flats [13]. Heinrich Rambold was the last artist in the region who created folkloristic reverse glass paintings as souvenirs for tourists. He focussed primarily on 19th-century templates of religious motifs including saints, votive pictures and titular saints in various sizes, but he also created his own designs in an expressive colour style [14]. Münter was the first one of the four to start with this technique by learning from Rambold and copying some of his paintings $[11,12]$. She also inspired Kandinsky to try this technique, and they spent evenings creating reverse paintings on glass with their own style and motifs. Traditional 19th-century reverse glass paintings reveal characteristic features like two-dimensional areas of unbroken colour, simplification of the forms, reduction of the colouration and dominance of the line. The combination of the graphic contour and pictorial elements was a contemporary achievement of non-academic pictorial art. The graphic enclosing of coloured areas also played an important role in the works of Paul Gauguin and of the members of the "Nabis" and "Fauves" groups. Jawlensky and Werefkin in particular, studied these French painters and discussed their observations with Kandinsky and Münter in Murnau. The four artists became enthusiastic about the intense and luminous paintings by Georges Braque, André Derain and Henri Matisse [15]. The same luminosity of colours can be found in the traditional Bavarian reverse glass paintings. Hence, for the "Blaue Reiter" artists, the "primitive" originality of the folkloristic reverse glass paintings corresponds to the modern pictorial principles of the avant-garde movements. To achieve a look of simplicity, nativeness and originality, the "Fauves" and "Brücke" artists searched for oriental and exotic artworks; however, the "Blauer Reiter" collective found these desired features in the folkloristic art of the surrounding rural area. There were no academic rules and guidelines for the technique of painting on the reverse side of a glass panel, so it became an important source of inspiration, that supported the striving for clarity of expression and simplification of composition. This led Münter and Kandinsky to consciously adapt their art to the pictorial principles of the folkloristic art.

\section{Wassily Kandinsky—reverse glass painter}

Kandinsky must have thought highly about this technique, as he created more than 70 reverse glass paintings in his career and allowed three of them to be shown in the first "Blaue Reiter" exhibition at the Moderne Galerie Thannhauser in Munich in 1911/12 [11]. His fascination and intense focus on the technical and stylistic opportunities of this technique are especially visible during his stays in Murnau and when he was finalizing his search for a fundamental, novel pictorial conception in 1911. Kandinsky also states in a letter to Franz Marc that he hardly knows any work that is more delightful than creating reverse glass paintings-unfortunately, these paintings are so fragile [16]. He continued with this technique during his stays in Moscow (1915-1921) and Paris (1933-1944). Besides Gabriele Münter and Heinrich Campendonk (1889-1957), Kandinsky created the largest number of reverse glass paintings among the artists associated with the "Blaue Reiter" collective, which 
further indicates that this genre plays a substantial role in his oeuvre.

His first glass painting dates from 1909, when, in contrast to Münter, he already starts with his own sketches (e.g. Mit Gelbem Pferd, 1909 and Abendmahl, 1909/10). After these first attempts, Kandinsky started to use typical stylistic elements like closed contours with dark lines. He painted motifs like saints, apocalyptic scenarios or All Saints' Day, which are in close relation to his early works (Fig. 1). Several pictorial topics and motifs were first painted on glass, and later executed on canvas or paper or as woodcut. For example, Kandinsky created two analogies of the reverse glass painting Allerheiligen I (1911) as a coloured woodcut and an oil painting on cardboard. Religious topics and motifs are especially present in his artworks from 1911 until 1914, where they express a hidden flow of encrypted symbols [17]. The reproduction of glass paintings with other techniques led to a loss of the aesthetic properties of the glass substrate. The interplay of the material iconography and the painted objects for reverse glass paintings has hardly been described in art historical research. However, Kandinsky used structured glass panels, like cathedral glass or ornamental glass for several works, that reveal an experimental character [18]. Three of them (Rudern, Mit Kneifer, Mit Reiter, all dated 1912) are listed in the catalogue raisonné and are explicitly described as paintings "on corrugated glass" [19]. Wackernagel states that Kandinsky wanted to distance himself from the folkloristic tradition of reverse glass painting by using structured or corrugated glass panels [20].

Kandinsky integrated the corrugation of the panel in Rudern (Fig. 2) as an independent stimulus and complicated the exploration of the subjects by integrating metal foils as collage-like objects [8]. The left half of the painting shows a boat that, as indicated by thick black brush strokes, is lifted by a big wave. The dimly visible people hold six oars that extend radially in pairs out of the boat. The entire glass panel is filled with colourful areas that do not depict specific objects. The combined use of structured glass and metal foils hinders a clear identification of the graphic elements, which indicates that the veiling of the motifs was done solely externally with technical media [8]. Hence, Kandinsky's paintings on structured glass panels seem to avoid a straightforward recognizability of the motifs. This can also be observed in his abstract canvas paintings, which he created in parallel from 1911 onwards. The corrugated glass structure of Rudern is not only an attractive material property, but also directly implies the representation of water and waves. The combined observation of the reflections from the metal foils and the glass surface can be interpreted as light reflections on the water. In 1910, Kandinsky created a watercolour painting that shows several similarities with Rudern: six black lines (the oars) with double arcs above, the continuous red line painted from the right to the left, and

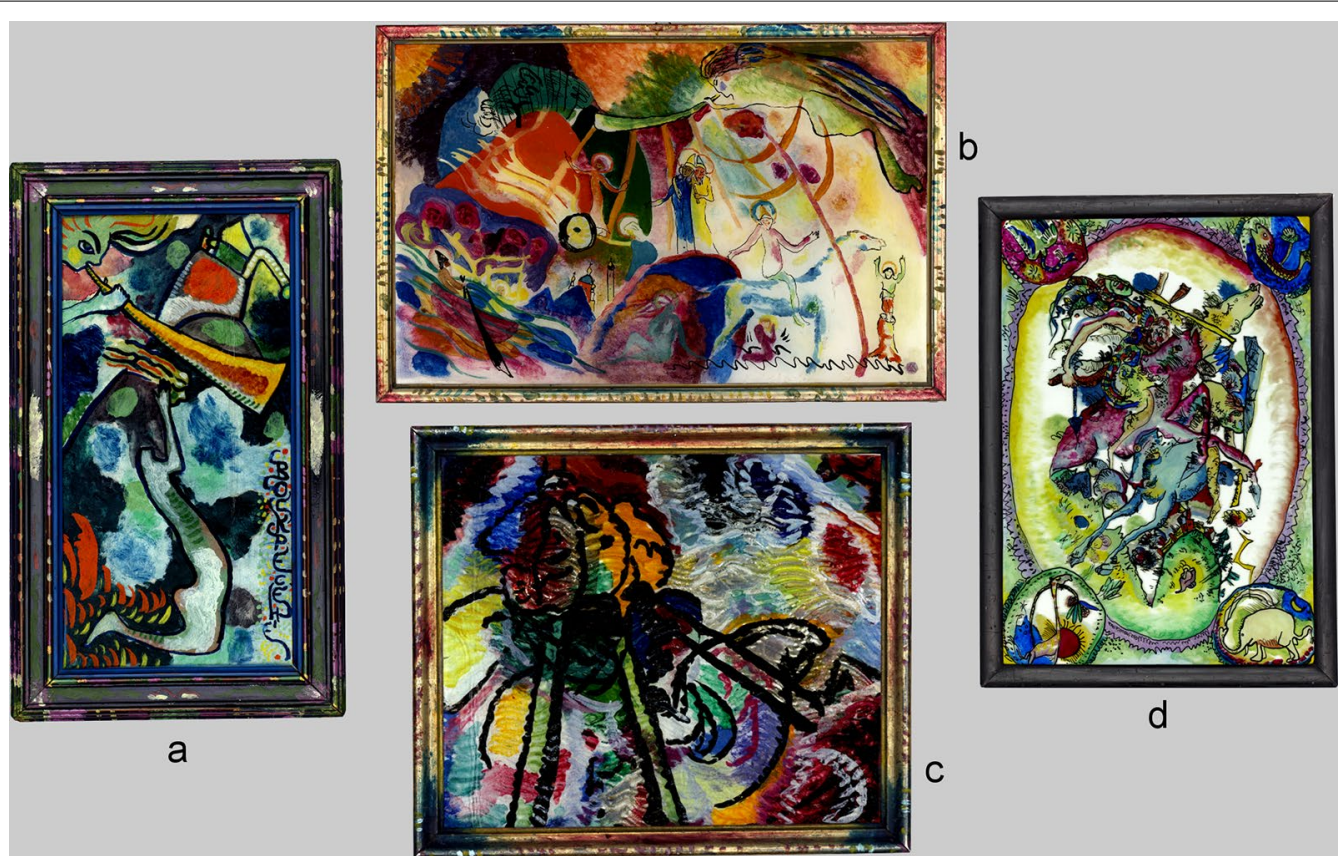

Fig. 1 Photographs of the framed paintings: a Auferstehung, 1911 (GMS 112), b Allerheiligen II, 1911 (GMS 122), c Rudern, c. 1912 (GMS 108$)$, d Apokalyptischer Reiter II, 1914 (GMS 106); OStädtische Galerie im Lenbachhaus und Kunstbau München 

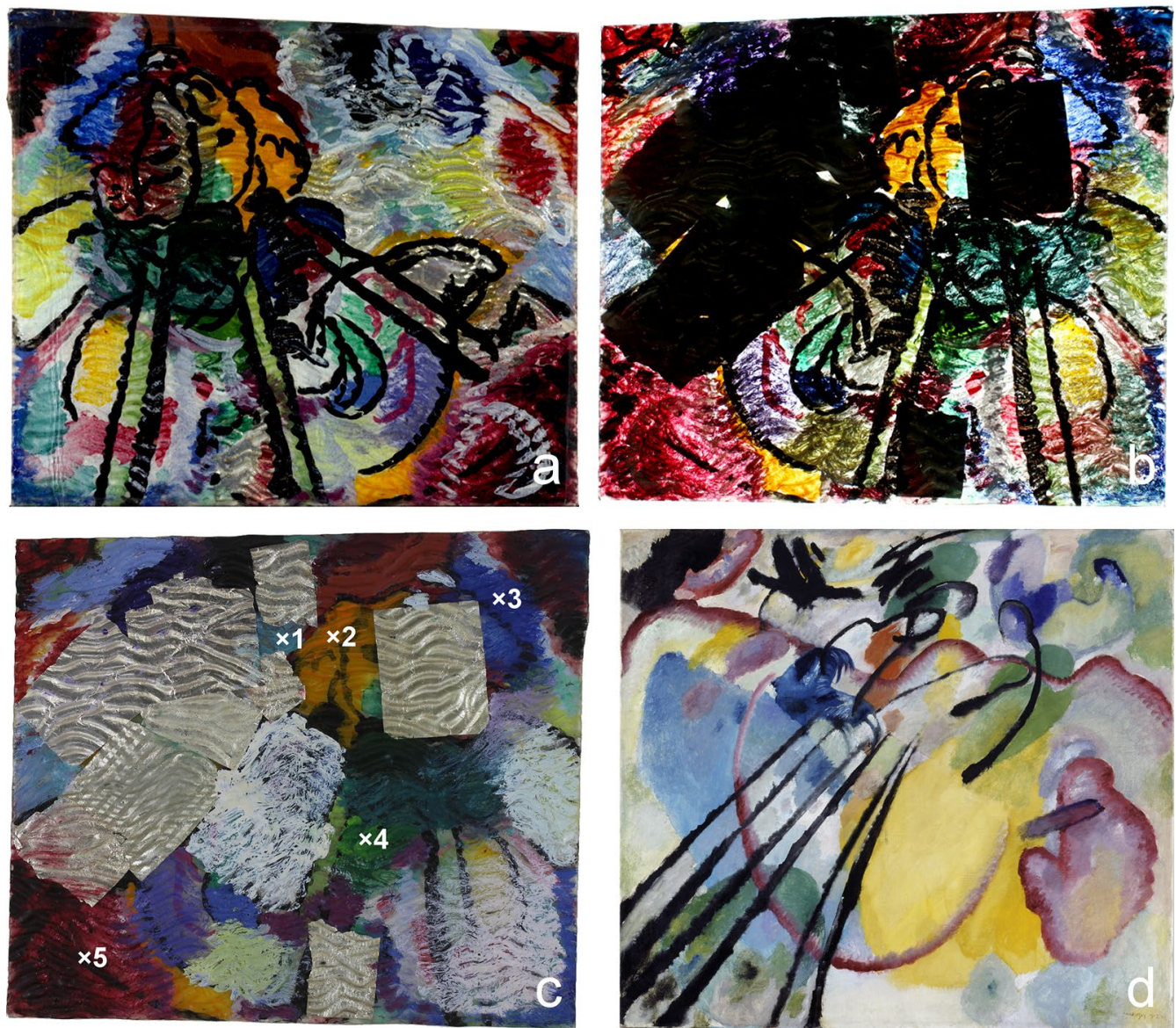

Fig. 2 Photographs of Rudern, c. 1912 (GMS 108), Städtische Galerie im Lenbachhaus und Kunstbau München (a-c): a unframed front side, b reverse side in transmitted light, c reverse side, along with a photograph of the canvas painting Improvisation 26 (Rudern), 1912 (GMS 66) (d). OStädtische Galerie im Lenbachhaus und Kunstbau München (a, d); @Simone Bretz (b, c)

the red, gently contoured area in the lower right part of the painting. The side-inverted illustration of the oblique oar lines indicates that Kandinsky used this watercolour painting as a draft for Rudern and for the canvas painting Improvisation 26 (Rudern) (Fig. 2d). The objects in the watercolour painting can still be read clearly, whereas the other two paintings show an advanced mystification of motifs. Kandinsky created Rudern and Improvisation 26 (Rudern) in a close context in 1912. The painting Improvisation 26 (Rudern) yields details of the drawing, the watercolour painting and the reverse glass painting; however, the illustration of the content becomes less clear as the motifs and forms further dissolve and as the colours gain greater importance, in direct contrast to the disappearing forms [8]. The painting appears more differentiated and the border between clear recognizability and mystification of the motifs remains fluent. The statements of Zweite [18] imply that the reverse glass painting Rudern was also a preliminary study for Improvisation 26 (Rudern); but unlike his drafts, drawings and sketches,
Kandinsky showed reverse glass paintings together with paintings on canvas in his exhibitions (e.g. gallery "Der Sturm") implying a coequal importance of the two techniques.

\section{Description of the paintings}

Four reverse glass paintings (Auferstehung, Allerheiligen II, Rudern, Apokalyptische Reiter II) by Wassily Kandinsky (Fig. 1), housed in the Städtischen Galerie im Lenbachhaus und Kunstbau in Munich, were examined during the research project "Hinterglasmalerei als Technik der Klassischen Moderne 1905-1955" (2015-2019). They were created between 1911 and 1914 in Murnau and stored in Kandinsky and Münter's villa after Kandinsky had to leave Germany in 1914. Kandinsky and Münter used Allerheiligen II and other reverse glass paintings to decorate their dining room as shown in a photograph taken by Münter in 1913 (Fig. 3). Kandinsky's reverse glass paintings remained in Murnau until 1957, when Münter donated them among other artworks to 


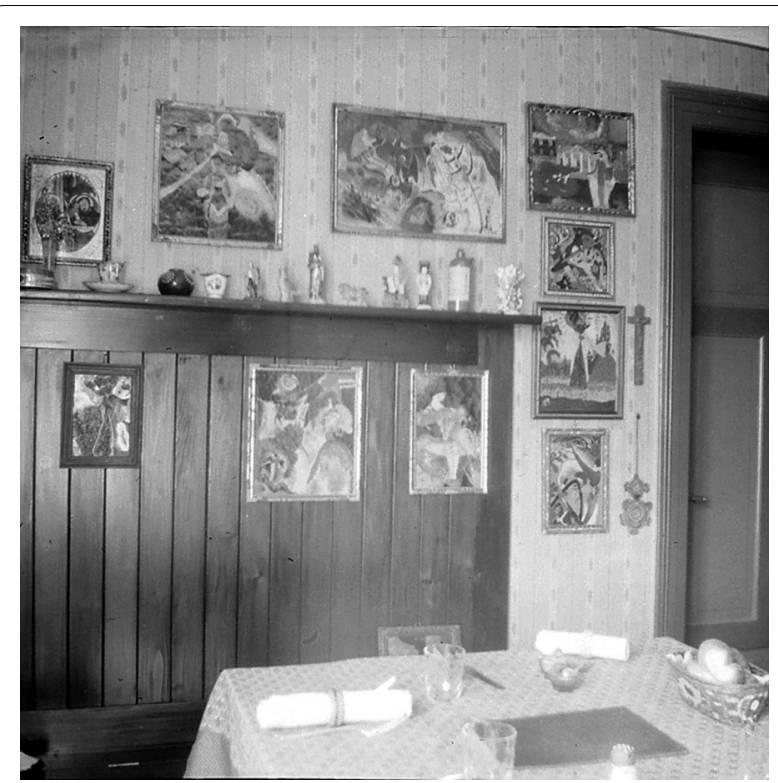

Fig. 3 The dining room of the Murnau house; the wall is decorated with reverse glass paintings by Kandinsky. Photo: Gabriele Münter (1913), Gabriele Münter- und Johannes Eichner-Stiftung, Munich (Inv.-Nr. 2235)/OVG Bild-Kunst, Bonn 2019

the Städtischen Galerie im Lenbachhaus und Kunstbau in Munich.

One of the four paintings (Allerheiligen II, 1911) is signed with the monogram "K". Münter wrote with a pencil "Kandinsky/Gemalt im August 1911/in Murnau"on the backing cardboard of Auferstehung (1911) and "Kandinsky (Glasbild) Rudern" on the backing layer of Rudern (c. 1912). Apokalyptischer Reiter II (Fig. 4) dates from
1914 and was the last reverse glass painting that Kandinsky created in Murnau. Moreover, as already discussed in the introduction to Rudern, Kandinsky created several paintings with the same content on different supports, like canvas, paper, cardboard and glass. In 1911, Kandinsky executed Allerheiligen $I I$ as a watercolour, canvas and as a reverse glass painting (Fig. 5). A glass fragment of the preliminary study for Apokalyptischer Reiter II from 1914 has been preserved, showing roughly painted lines on the upper part of the painting. The analogue watercolour painting dates from 6 . July 1914 and shows the same central motifs in a mirror image, but the oval cartouche and the four illustrations of animals on the edges are missing.

\section{Painting technique}

The major artistic challenge of painting on the reverse side of a glass panel may be the reverse succession of the paint layers. Kandinsky had to apply the frontmost layer (i.e. the most visible layer) first and the background layer last. He started his paintings with black contours and lines, followed by the detailed painting of internal areas and the application of the background.

The four paintings reveal multi-layered paint systems (2-3 layers) showing variably thick paint layers. Kandinsky used a variety of brushes and stippled the paint or swiftly coloured large areas. He painted wet-in-wet or applied the paint as dots side by side or one upon another, indicating an optical mixture of colours. The typical structure of an inhomogeneous application of colour indicates the use of a bristle brush in several areas of Rudern (Fig. 2b, c), whereas the white area of the painting seems to be stippled. Compared with Rudern, the application of paint layers in Auferstehung (Fig. 6) was more
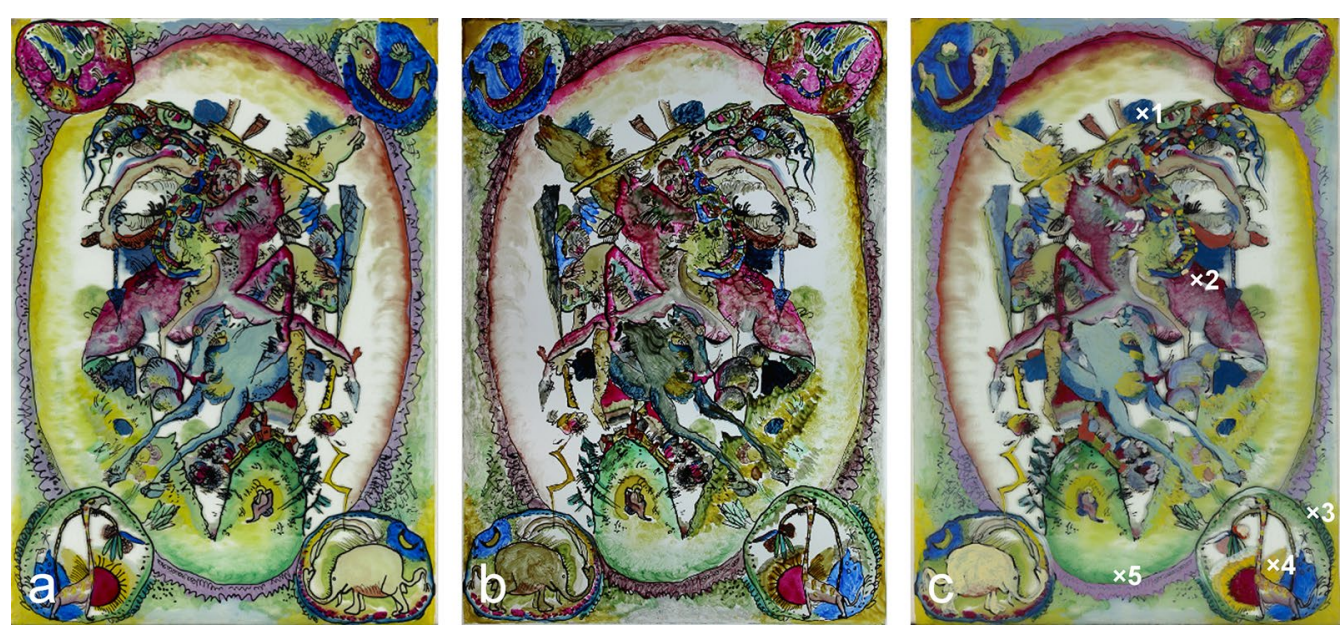

Fig. 4 Photographs of Apokalyptischer Reiter II, 1914 (GMS 106), Städtische Galerie im Lenbachhaus und Kunstbau München: a unframed front side, b reverse side in transmitted light, c reverse side. OStädtische Galerie im Lenbachhaus und Kunstbau Munich (a); @Simone Bretz (b, c) 

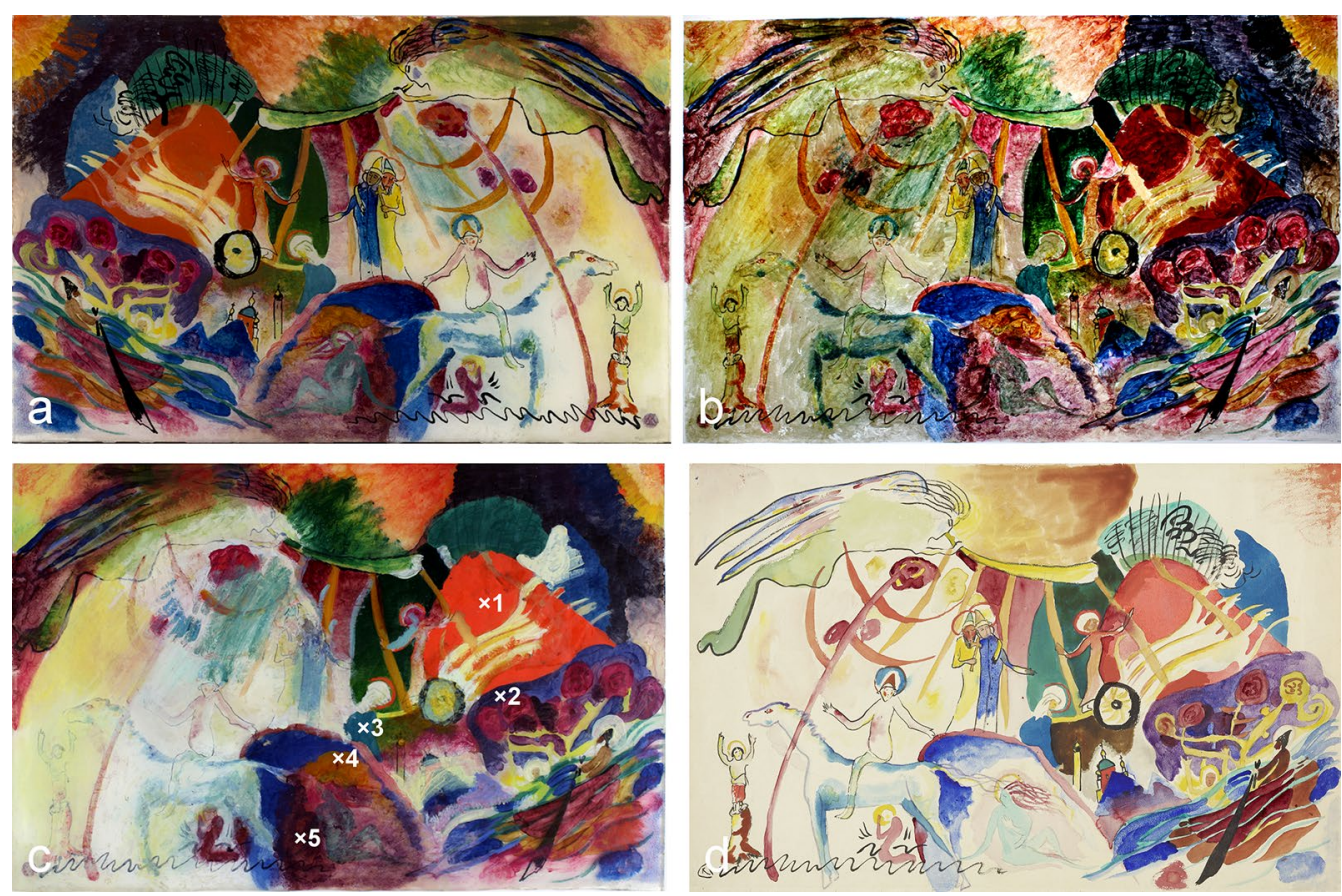

Fig. 5 Photographs of Allerheiligen II, 1911 (GMS 122), Städtische Galerie im Lenbachhaus und Kunstbau München (a-c); a unframed front side, b reverse side in transmitted light, $\mathbf{c}$ reverse side, along with a photograph of the watercolour painting Allerheiligen II, 1911 (GMS 616), Städtische Galerie im Lenbachhaus und Kunstbau München (d). OStädtische Galerie im Lenbachhaus und Kunstbau München (a, d); @Simone Bretz (b, c)
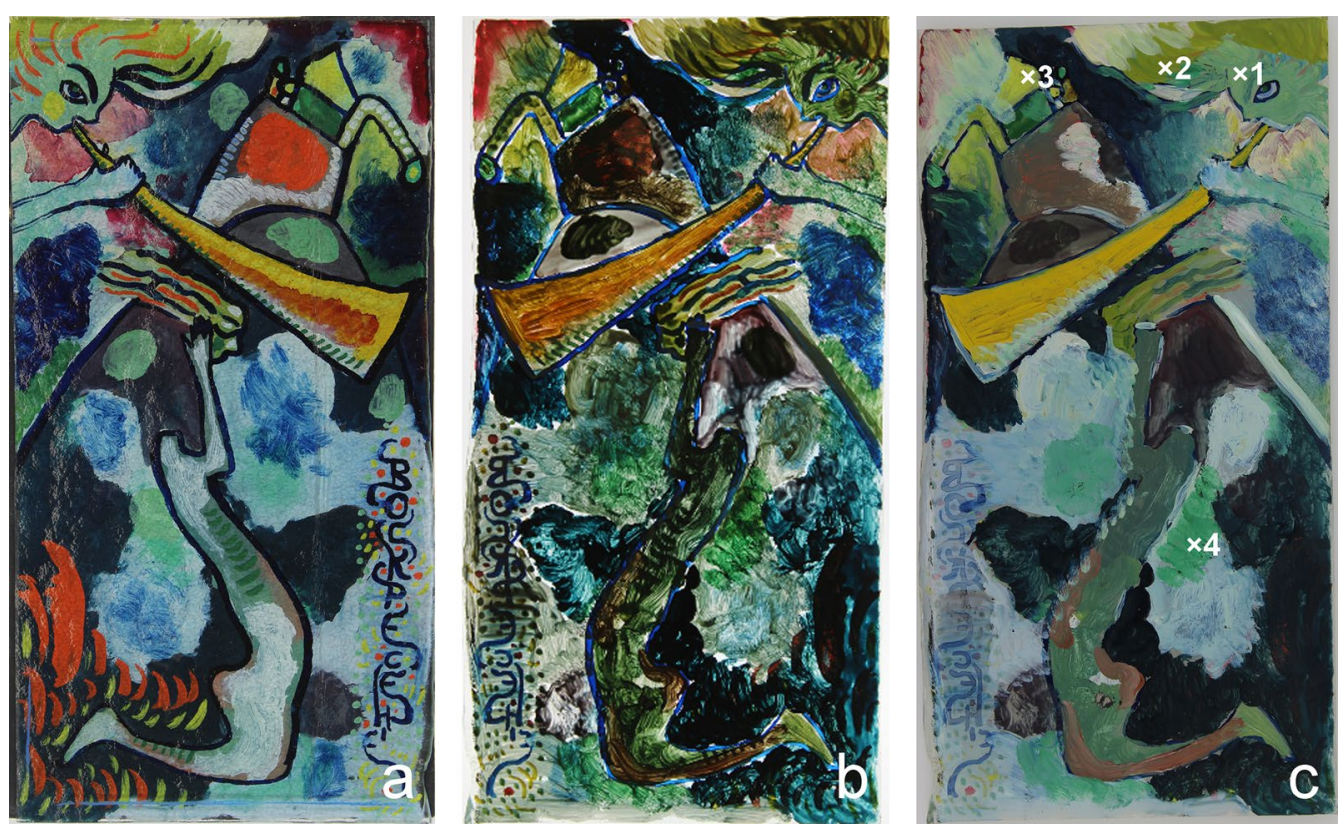

Fig. 6 Photographs of Auferstehung, 1911 (GMS 112), Städtische Galerie im Lenbachhaus und Kunstbau München; a unframed front side, b reverse side in transmitted light, c reverse side. @Städtische Galerie im Lenbachhaus und Kunstbau München (a); @Simone Bretz (b, c) 
intense and homogeneous. One needs to consider that these paintings make their impressions solely from the front side, hence the gloss, brush structure, and pastosity of the reverse side were not of artistic importance.

Kandinsky often used cardboards painted black as supports for his reverse glass paintings as they further intensify the depth of colours [21]. Such black-painted cardboard was used in Auferstehung, Allerheiligen II and Rudern. Black-painted supports (paper or wooden veneer) are also known from traditional Bavarian and Swiss reverse glass paintings from the 18th and 19thcentury respectively [22]. 19th-century Bavarian reverse glass paintings may also have been Kandinsky's source of inspiration to decorate the frames of his paintings (Fig. 1). The folkloristic paintings from Oberammergau, in particular, have black frames painted with flower motifs. Kandinsky used a commercial wooden frame for Auferstehung, which he decorated with green, blue and violet paints (Fig. 1). He chose industrially gilded frames for the other three paintings, which he partially overpainted with lustre paint (Fig. 1).

\section{Glass technique}

For paintings on canvas, the final application of varnish creates a certain depth of colours and protects the uppermost paint layers. The glass panel of reverse glass paintings, however, itself behaves as a varnish, which gives rise to the painting's great luminosity and protects the paint layers from the front. Kandinsky used glass panels of variable sizes in landscape and portrait format. The glass panels of the studied paintings show the following dimensions: $21.9 \times 11.4 \times 0.28$ (Auferstehung), $31.1 \times 47.8 \times 0.41$ (Allerheiligen II), $21.5 \times 25.7 \times 0.44 \quad$ (Rudern) and $30.3 \times 21.2 \times 0.25 \mathrm{~cm}$ (Apokalyptischer Reiter II). The surface structure of the glass panel plays an important role for the final visual appearance of a reverse painting on glass. Generally, artists prefer flat glass panels, because light reflections of an uneven surface distract the observer's attention from the painted motifs. Kandinsky created most of his reverse glass paintings on flat panels, but ten paintings on structured glass are known from his Murnau period between 1911 and 1913. He used commercial products, that were sold for different applications (e.g. windows). Generally, there were two different types of structured glass panels: ornamental glass (3-4 mm thick) that shows a corrugated surface and the thinner cathedral glass $(2-3 \mathrm{~mm})$ that reveals a "hammered" surface structure (Fig. 7a). Both types were produced in the rolling process, which was invented in 1847 [23]. Rolled plate glass was made by thinning molten glass between two rollers and then placing it on the casting table. The surface structure of ornamental glass was first engraved into the table in which the molten glass was then cast. This procedure was expensive, so the process was adapted in 1884; now the structures were engraved in an extra pair of rollers, which pressed into the already thinned glass [23]. The rolling process for cathedral glass included a higher temperature and a faster rolling procedure, and the thinned glass was drawn out on a water-cooled casting table. The quick cooling led to a quick contraction of the glass surface, yielding a "hammered" appearance of the surface. The other, rolled side of the glass panel was not affected by this procedure and stayed rather smooth. Kandinsky did not always choose the same side to paint onto. In Auferstehung, the structured surface is the front side (Fig. 7a), whereas for Allerheiligen II, the smoother surface is the front side (i.e. he painted on the structured side). In Rudern, Kandinsky painted on the corrugated side of the ornamental glass (Fig. 2c).
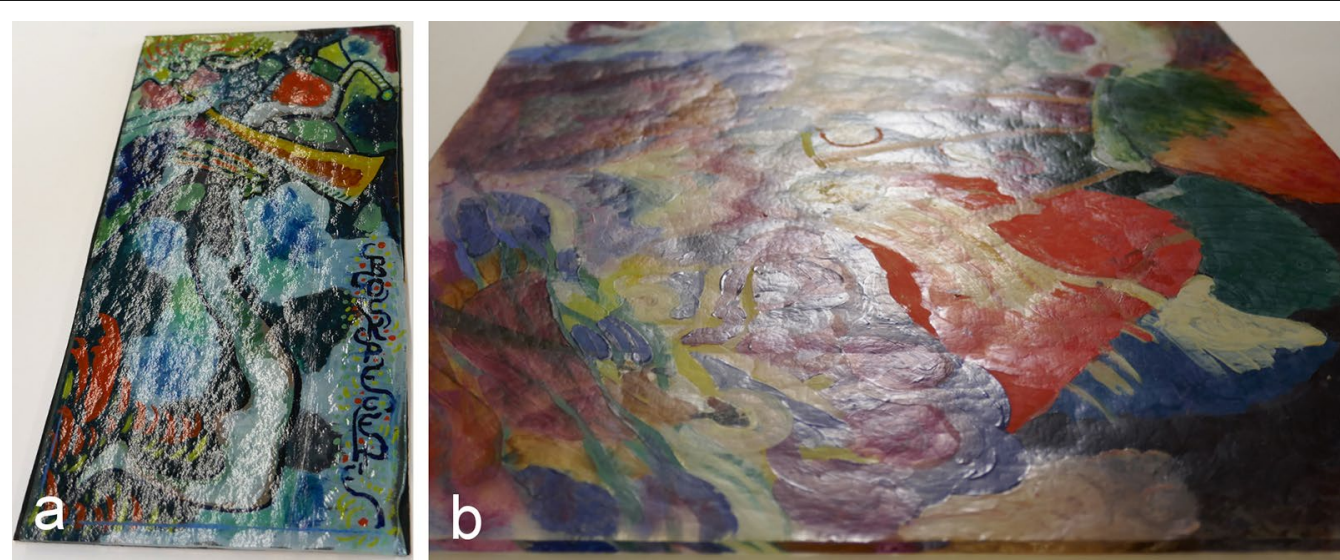

Fig. 7 Photographs of $\mathbf{a}$ Auferstehung (front side) and $\mathbf{b}$ Allerheiligen I/ (reverse side) in glancing light, showing the structured surface of the cathedral glass. OSimone Bretz 


\section{Methods of the material analyses}

\section{X-ray fluorescence (XRF)}

The handheld spectrometer Tracer III-SD (Bruker AXS Microanalysis $\mathrm{GmbH}$ ) was fixed on a tripod perpendicularly to the sample (sample to spectrometer distance $\sim 1 \mathrm{~mm}$, spot size $\sim 10 \mathrm{~mm}$ ). The instrument consists of an electrothermally cooled Xflash SDD detector (energy resolution $=150 \mathrm{eV}$ for $\mathrm{Mn} \mathrm{K} \alpha$ radiation) and an X-ray tube equipped with a rhodium anode. The excitation parameters were set to $40 \mathrm{kV}, 15 \mu \mathrm{A}$ and $20 \mathrm{~s}$ (acquisition time).

\section{VIS spectroscopy (VIS)}

The spectrophotometer SPM 100 (Gretag-Imaging AG, Regensdorf, Switzerland), measures the reflection of visible light (from 380 to $730 \mathrm{~nm}$ ) with a spectral resolution of $10 \mathrm{~nm}$. The surface of the sample is illuminated for half a second, using a $2 \mathrm{~W}$ bulb (spot size $4 \mathrm{~mm}$ ). The reflectance spectra are normalized, and the first derivative is plotted for better peak comparison.

\section{Diffuse reflectance infrared fourier transform spectroscopy (DRIFTS)}

Diffuse reflectance spectra were recorded, using a 4100 Exoscan FTIR spectrometer (Agilent) fixed on a tripod perpendicularly to the sample (sample to spectrometer distance $\sim 1 \mathrm{~mm}$, spot size $\sim 10 \mathrm{~mm}$ ). In this configuration, the reflected signal is collected inside an imaginary cone of $45^{\circ}$ around the emission beam, which supports the detection of diffuse reflected light. The instrument is equipped with a ZnSe beam splitter, a Michelson interferometer and a thermoelectrically cooled dTGS detector. For every spectrum, 500 scans were recorded in the mid IR range $\left(650-4000 \mathrm{~cm}^{-1}\right)$ with a spectral resolution of $4 \mathrm{~cm}^{-1}$. A gold reference cap was used for background calibration. The spectrum intensity was defined as pseudo-absorbance $\mathrm{A}^{\prime}=\log (1 / \mathrm{R})$. The Thermo Scientific $^{\mathrm{TM}}$ OMNIC ${ }^{\mathrm{TM}}$ Specta software (Version 9.7, Madison, WI, USA.) was used for comparison with internal databases.

\section{Raman spectroscopy}

Raman measurements were performed with an i-Raman ${ }^{\circledR}$ Plus spectrometer (B\&W Tek Inc.) equipped with a handheld fibre optic probe and a CCD detector. The probe was connected to a microscope head (BAC151B, B\&W Tek Inc.) with an Olympus $50 \times$ objective and was fixed on a motorized xyz stage of a tripod. After focusing through the microscope, the maximum laser power of the $785 \mathrm{~nm}$ diode laser was $\sim 160 \mathrm{~mW}$. The recorded spectra range from 100 to $3300 \mathrm{~cm}^{-1}$ (spectral resolution $4 \mathrm{~cm}^{-1}$ ) with varying acquisition parameters of $1-200 \mathrm{~s}$ and $2-10 \%$ laser power. The holographic grating was fixed at 1200 lines $/ \mathrm{mm}$. The Thermo Scientific ${ }^{\text {TM }}$ $\mathrm{OMNIC}^{\mathrm{TM}}$ Specta software (Version 9.7, Madison, WI, USA.) was used for baseline correction and for comparison with internal databases.

\section{Analytical results}

The reverse side of Auferstehung (1911) (Fig. 6c) is dominated by yellow, green and bluish colours. These areas partly cover the orange and red areas, that are visible from the front side. Zinc white $(\mathrm{ZnO})$ and smaller amounts of lead white $\left(2 \mathrm{PbCO}_{3} \cdot \mathrm{Pb}(\mathrm{OH})_{2}\right)$ were present in all coloured areas, whereas the white uppermost layer consists only of zinc white. A small amount of Gypsum $\left(\mathrm{CaSO}_{4} \cdot 2 \mathrm{H}_{2} \mathrm{O}\right)$ was detected and other fillers were absent. Prussian blue $\left(\mathrm{Fe}_{4}\left[\mathrm{Fe}(\mathrm{CN})_{6}\right]_{3}\right)$ was used solely for the blue and dark blue painted areas. The dominant green hues of the reverse side comprise mainly mixtures of Prussian blue with various yellows. Strontium, Naples and chrome yellow were admixed to achieve greenish yellow to bluish green hues. Strontium yellow $\left(\mathrm{SrCrO}_{4}\right)$ and chrome yellow $\left(\mathrm{PbCrO}_{4}\right)$ were also individually used for the yellow and dark yellow areas. Both pigments yield fingerprinting Raman spectra. Strontium yellow shows typical $\mathrm{CrO}_{4}$ bending modes at 338, 349, 372, 400 and $431 \mathrm{~cm}^{-1}$ and intense $\mathrm{CrO}_{4}$ stretching bands at $865\left(v_{\mathrm{s}}\right)$, 892 and $914 \mathrm{~cm}^{-1}\left(v_{\mathrm{as}}\right)$ (Fig. 8e) [24, 25]. The intense Raman band at $838 \mathrm{~cm}^{-1}\left(\mathrm{CrO}_{4}\right.$ stretching) along with several weaker ones at 344, 358, 375 and $399 \mathrm{~cm}^{-1}\left(\mathrm{CrO}_{4}\right.$ bending) (Fig. 8f) properly identify chrome yellow in the greenish yellow area (Fig. 6c, spot 2) [26]. Characteristic bands at 278, 535 (FeC stretching), 2094 and $2154 \mathrm{~cm}^{-1}$ (CN stretching) prove the presence of Prussian blue [27, 28]. An additional weak spectral feature at $251 \mathrm{~cm}^{-1}$ originates from an underlying layer and can be ascribed to cinnabar $(\mathrm{HgS})$. Intense $\mathrm{Sb}$ peaks in the XRF spectrum of the bluish green areas (e.g. Fig. 6c, spot 1) hint at Naples yellow $\left(\mathrm{Pb}_{2} \mathrm{Sb}_{2} \mathrm{O}_{7}\right)$. Due to extensive fluorescence, it was not possible to record a usable Raman spectrum from these areas. However, Naples yellow yields one major band in the mid IR range, so it could be identified using DRIFTS (Fig. 8a). The prominent inverted and broad band (reststrahlen band) shows a minimum at $675 \mathrm{~cm}^{-1}$, whereas the other IR active modes are out of range for this device $[29,30]$. The DRIFT spectrum also reveals an intense band at $2098 \mathrm{~cm}^{-1}$ originating from Prussian blue (CN asymmetric stretching) [31]. Despite this variety of mixed greens, Kandinsky also used a green pigment. The XRF spectrum of spot 4 (Fig. 6c) is dominated by $\mathrm{Cr}$ and $\mathrm{Sr}$ signals, suggesting the presence of viridian (hydrated chromium oxide) and strontium yellow. Both pigments were detected in the DRIFT spectrum (Fig. 8b). Viridian yields a typical weak band at $1064 \mathrm{~cm}^{-1}$ and two spectral 

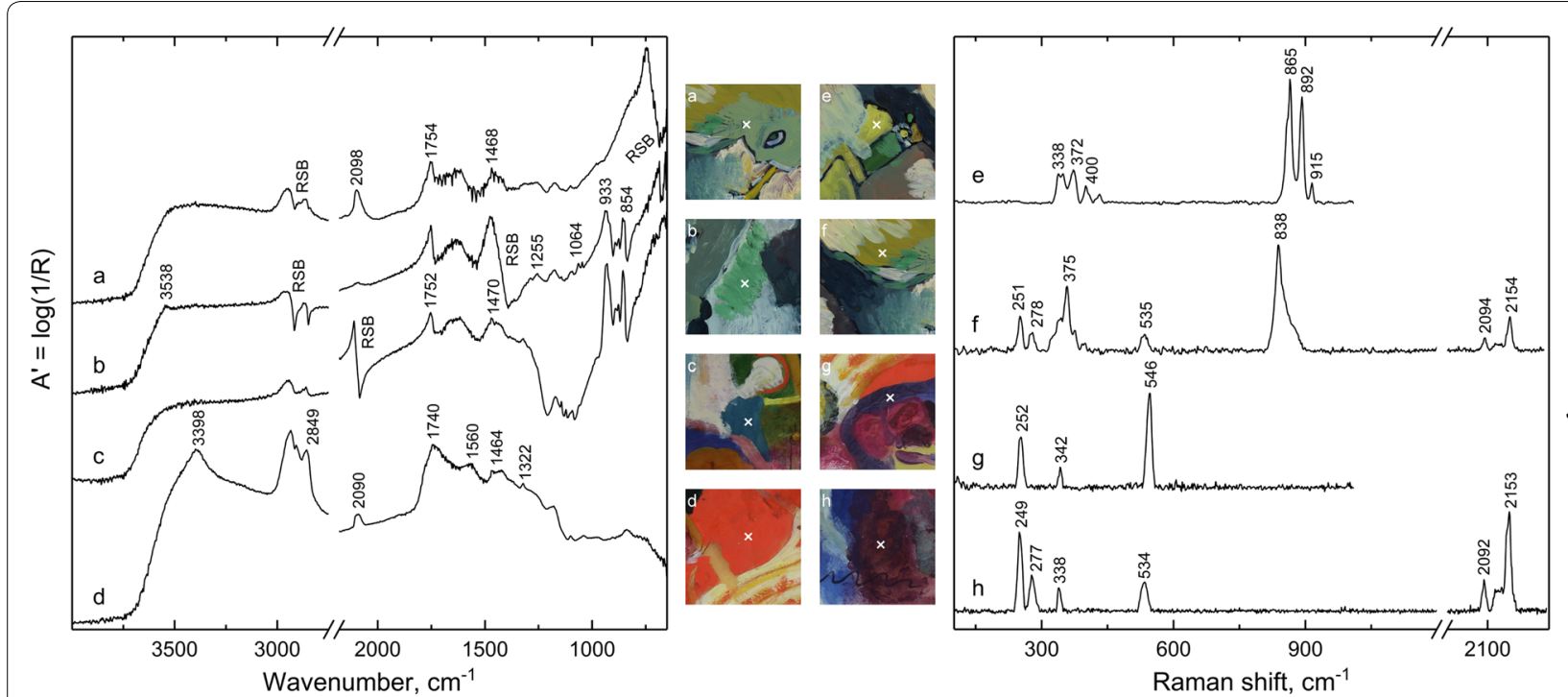

Fig. 8 DRIFTS $(a-d)$ and Raman spectra (e-h) of Auferstehung $(a, b ; e, f)$ and Allerheiligen II $(c, d ; g, h)$ along with detailed photos of the measured areas; offset was applied for better comparison. DRIFT spectra originate from the following spots: a) the green area of Fig. $4 \mathrm{c}($ spot 1$)$, b) the green area of Fig. 4c (spot 4); c) the bluish green area of Fig. $5 \mathrm{c}$ (spot 3), and d) the orange area of Fig. $5 \mathrm{c}$ (spot 1); RSB = reststrahlen band. Raman spectra originate from the following spots: e) the yellow area of Fig. $4 \mathrm{c}($ spot 3$), \mathrm{f})$ the greenish yellow area of Fig. $4 \mathrm{c}(\mathrm{spot} 2) ; \mathrm{g})$ the violet area of Fig. $5 \mathrm{c}$ (spot 2), and h) the pinkish red area of Fig. $5 c$ (spot 5). $\times=$ measured spots

features at 1255 and $1287 \mathrm{~cm}^{-1}$ originating from chromium borate, a by-product from the production process of the pigment [32]. Strontium yellow shows intense bands at 854, 876 and $933 \mathrm{~cm}^{-1}$. Additionally, several lead white bands also appear in the spectrum: $1046\left(\mathrm{CO}_{3}\right.$ symmetric stretching), $3538 \mathrm{~cm}^{-1}(\mathrm{OH}$ stretching) and an inverted band with a minimum at $1392 \mathrm{~cm}^{-1}\left(\mathrm{CO}_{3}\right.$ antisymmetric stretching) [7]. The presence of cinnabar and brown earth pigments in the red-orange and brown areas was confirmed by XRF respectively. All measured areas yield typical bands for drying oil. An example is given in Fig. 8a, showing bands at $1468\left(\mathrm{CH}_{2}\right.$ scissoring) and $1754(\mathrm{C}=\mathrm{O}$ stretching $) \mathrm{cm}^{-1}$ and inverted spectral features with minima at 2848 and $2915 \mathrm{~cm}^{-1}\left(\mathrm{CH}_{2}\right.$ stretching) $[7,8,33]$.

The palette of Allerheiligen II (1911) (Fig. 5a-c) is summarized in Table 1. Zinc white and, in minor amounts, lead white were found in all colours. Gypsum was identified only in the bluish green areas, whereas other fillers (e.g. barium sulfate, chalk) are again absent. The thin contour lines and black areas were painted with carbon black. Prussian blue and ultramarine blue $\left(\mathrm{Na}_{7} \mathrm{Al}_{6} \mathrm{Si}_{6} \mathrm{O}_{24} \mathrm{~S}_{3}\right)$ were individually used for the blue areas, and both were mixed with cinnabar to create violet and pinkish red hues (Fig. 5c, spots 2 \& 5). The Raman spectrum of the bluish violet area (Fig. 8g) shows an intense ultramarine blue band at $546 \mathrm{~cm}^{-1}$ (stretching of the $\mathrm{S}_{3}{ }^{-}$radical ion) and two bands at 252 and $342 \mathrm{~cm}^{-1}$ originating from $\mathrm{HgS}$ stretching vibrations of cinnabar
[34-36]. Raman measurements of a pinkish violet area (Fig. 8h) also yielded typical cinnabar bands at 249 and $338 \mathrm{~cm}^{-1}$ along with bands of Prussian blue at 338, 534, 2092 and $2153 \mathrm{~cm}^{-1}$. Kandinsky mixed Prussian blue in various ratios with strontium yellow and minor amounts of cadmium yellow to obtain bluish green and green hues (Fig. 5c, spot 3). Both major pigments can be clearly identified by their DRIFT spectra (Fig. 8c), as Prussian blue yields an intense reststrahlen band with a minimum at $2084 \mathrm{~cm}^{-1}$ (CN asymmetric stretching) and strontium yellow reveals its strong IR bands at 856, 878 and $931 \mathrm{~cm}^{-1}$ [31]. The yellow hues were created with a mixture of strontium yellow with minor amounts of cadmium yellow. The brownish to dark yellow areas (Fig. 5c, spot 4) yielded intense $\mathrm{Cd}, \mathrm{S}, \mathrm{Zn}$ and $\mathrm{Pb}$ signals in the XRF spectrum, suggesting the presence of zinc white, lead white and cadmium yellow (CdS). The DRIFT spectrum (Fig. 9c) of the same area shows a sharp inverted band with a minimum at $855 \mathrm{~cm}^{-1}\left(\mathrm{CO}_{3}\right.$ out of plane bending) and a weak combination band at $2472 \mathrm{~cm}^{-1}$, which can be assigned to cadmium carbonate $\left(\mathrm{CdCO}_{3}\right)$ $[37,38]$. A detailed interpretation is given in the section below (cf. "Analytical results" section). Drying oil was classified in most DRIFT spectra as binding media, yielding bands at 1470, $1752 \mathrm{~cm}^{-1}$ and two spectral features in the $2840-2930 \mathrm{~cm}^{-1}$ range (Fig. 8c) [7]. Only the spectrum of the orange area gives a hint at a different binder (Fig. 8d), showing a broad band at $1560 \mathrm{~cm}^{-1}$, which can be ascribed to the amide II of a proteinaceous compound 
Table 1 Comparison of the analytical results of the four paintings

\begin{tabular}{|c|c|c|c|c|}
\hline & $\begin{array}{l}\text { Auferstehung (Jüngstes } \\
\text { Gericht), } 1911 \text { ( } 23 \text { spots tested) }\end{array}$ & $\begin{array}{l}\text { Allerheiligen II, } 1911 \text { (34 spots } \\
\text { tested) }\end{array}$ & $\begin{array}{l}\text { Rudern, c. } 1912 \text { ( } 27 \text { spots } \\
\text { tested) }\end{array}$ & $\begin{array}{l}\text { Apokalyptischer Reiter II, } 1914 \\
\text { (32 spots tested) }\end{array}$ \\
\hline White & $\begin{array}{l}\text { Zinc white }{ }^{a} \text {, lead white }{ }^{a, c}, \\
\text { gypsum }{ }^{c}\end{array}$ & $\begin{array}{l}\text { Zinc white }{ }^{a} \text {, lead white }{ }^{a, c}, \\
\text { gypsum }{ }^{c}\end{array}$ & $\begin{array}{l}\text { Zinc white }{ }^{a} \text {, lead white }{ }^{a}, \text { gypsum}^{c} \text {, } \\
\text { barium sulfate }{ }^{a, c}\end{array}$ & $\begin{array}{l}\text { Zinc white }{ }^{a} \text {, lead white }{ }^{a} \text {, barium } \\
\text { sulfate }^{a, b}\end{array}$ \\
\hline Black & $-^{e}$ & Carbon black ${ }^{b}$ & Carbon black ${ }^{\mathrm{b}}$, bone black ${ }^{\mathrm{a}}$ & Carbon black? \\
\hline Red & Cinnabar ${ }^{a, b}$ & - & PR83 & Cinnabar $^{\mathrm{a}, \mathrm{d}}, \mathrm{PR} \mathrm{O}^{\mathrm{b}}$ \\
\hline Orange & - & Cinnabar + cadmium yellow ${ }^{\mathrm{a}, \mathrm{d}}$ & - & - \\
\hline Yellow & $\begin{array}{l}\text { Chrome yellow }{ }^{\mathrm{a}, \mathrm{b}} \text {, strontium } \\
\text { yellow }{ }^{\mathrm{a}, \mathrm{b}, \mathrm{c}}, \text { Naples yellow }^{\mathrm{a}, \mathrm{c}}\end{array}$ & $\begin{array}{l}\text { Strontium yellow + cadmium } \\
\text { yellow }{ }^{a, b, c, d}, \text { cadmium yellow } w^{a, c}\end{array}$ & $\begin{array}{l}\text { Strontium yellow }{ }^{a, b, c, d}, \text { cadmium } \\
\text { yellow }{ }^{a, d} \text {, yellow SOPc }\end{array}$ & $\begin{array}{l}\text { Cadmium yellow }{ }^{\mathrm{a}, \mathrm{d}}, \text { cadmium yel- } \\
\text { low + strontium yellow }{ }^{\mathrm{a}, \mathrm{c}, \mathrm{d}}\end{array}$ \\
\hline Green & $\begin{array}{l}\text { Viridian + strontium yellow }{ }^{\mathrm{a}, \mathrm{c}} \text {, } \\
\text { Prussian blue + chrome } \\
\text { yellow }{ }^{\text {a.c }}, \text { Prussian blue + stron- } \\
\text { tium yellow } \text {, Prussian } \\
\text { blue + Naples yellow }{ }^{a, b, c}\end{array}$ & $\begin{array}{l}\text { Prussian blue + strontium yel- } \\
\text { low + cadmium yellow }{ }^{a, c}\end{array}$ & $\begin{array}{l}\text { Viridian + strontium yellow }{ }^{\mathrm{a}, \mathrm{d}}, \\
\text { Prussian blue + strontium } \\
\text { yellow + cadmium yellow }{ }^{\mathrm{a}, \mathrm{b}, \mathrm{c}}, \\
\text { Prussian blue + yellow SOPc, } \\
\text { PB52 + yellow SOPc }\end{array}$ & $\begin{array}{l}\text { Viridian + strontium yellow }{ }^{a, c, d}, \\
\text { emerald green + strontium } \\
\text { yellow } w^{a, c}, \text { viridian + emerald } \\
\text { green + strontium yellow }{ }^{a, c}\end{array}$ \\
\hline Blue & Prussian blue $e^{a, b, c}$ & $\begin{array}{l}\text { Prussian blue } e^{a, b c, d}, \text { ultramarine } \\
\text { blue } e^{a, b, c, d}\end{array}$ & $\begin{array}{l}\text { Prussian blue } e^{b, c}, \text { ultramarine } \\
\text { blue }^{b, c}, \text { PB5 } 2^{b, c}\end{array}$ & $\begin{array}{l}\text { Prussian blue } e^{a, b, c, d}, \text { ultramarine } \\
\text { blue }^{a, b, d}, \text { cobalt blue }^{a}\end{array}$ \\
\hline Violet & Prussian blue + cinnabar ${ }^{a, b, c}$ & $\begin{array}{l}\text { Prussian blue + cinnabar }{ }^{a, b, c}, \\
\text { ultramarine blue + cinnabar }{ }^{a, b, c}\end{array}$ & Ultramarine blue + PR83 ${ }^{\mathrm{a}, \mathrm{c}}$ & $\begin{array}{l}\text { Prussian blue }+ \text { PR60 } 60^{a, b, c}, \text { cobalt } \\
\text { blue }+ \text { PR60 } 60^{a, b}\end{array}$ \\
\hline Brown & Brown earths ${ }^{a}$ & - & Brown earths $s^{a, c, d}$ & - \\
\hline Metal & - & - & Aluminium foil ${ }^{\mathrm{a}}$, tin foil ${ }^{\mathrm{a}}$ & - \\
\hline Binder & Drying oil ${ }^{c}$ & $\begin{array}{l}\text { Drying oil }{ }^{c} \text {, proteinaceous } \\
\text { binder }+ \text { lipids }^{c}\end{array}$ & Drying oil ${ }^{\complement}$ & Drying oil ${ }^{c}$ \\
\hline \multicolumn{5}{|c|}{ SOP synthetic organic pigment } \\
\hline \multicolumn{5}{|l|}{ a $\mathrm{XRF}$} \\
\hline \multicolumn{5}{|l|}{${ }^{c}$ DRIFTS } \\
\hline \multicolumn{5}{|l|}{ d VIS } \\
\hline colou & 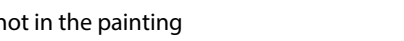 & & & \\
\hline
\end{tabular}

(e.g. egg white, casein), along with intense signals (1740, 2858, $2935 \mathrm{~cm}^{-1}$ ) of lipids (oil, egg yolk) [7]. The spectral feature at $1464 \mathrm{~cm}^{-1}$ may be a combination of the amide

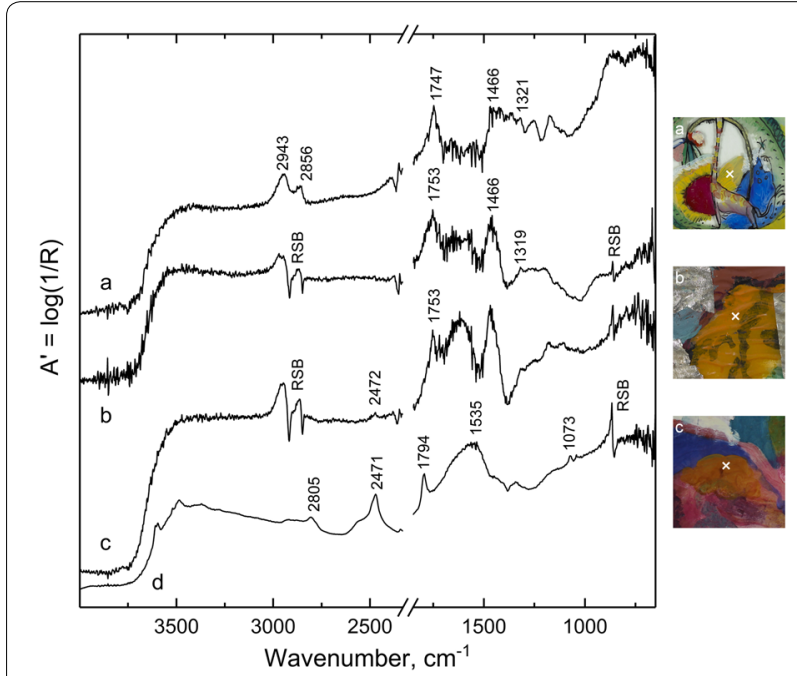

Fig. 9 DRIFT spectra of yellow areas of a) Apokalyptischer Reiter II (Fig. 6c, spot 4), b) Rudern (Fig. 3c, spot 2) and c) Allerheiligen II (Fig. 5c, spot 4) along with a cadmium carbonate powder spectrum (d). $\mathrm{RSB}=$ reststrahlen band. $\times=$ measured spots
III band from the protein and the $\mathrm{CH}_{2}$ scissoring vibration of the fatty compound. Additionally, a weak band of an oxalate $\left(1322 \mathrm{~cm}^{-1}\right)$ [39] and one of an unknown substance $\left(3398 \mathrm{~cm}^{-1}\right)$ are visible.

The reverse side of Rudern (c. 1912) is partly covered with aluminium and tin foils (glossy silvery appearance and whitish matt, respectively) (Fig. 2c) showing different surface structures (Fig. 10b). Zinc white dominates among the white pigments, while lead white appears in small amounts. Gypsum was found only in the brown painted area, associated with iron oxides. The use of barium sulfate $\left(\mathrm{BaSO}_{4}\right)$ is restricted mainly to some greenish areas that contain synthetic organic pigments (SOP). Kandinsky used pure carbon black for the thick contour lines and bone black $\left(\mathrm{C}+\mathrm{Ca}_{5}\left(\mathrm{PO}_{4}\right)_{3}(\mathrm{OH})\right)$ for the black painted area. Ultramarine blue was identified in the blue areas by its intense Raman band at $546 \mathrm{~cm}^{-1}$ (Fig. 11f). The light greenish blue hues (Fig. 2c, spot 1) originate from anthraquinone lake, PB52, which is partly mixed with Prussian blue. PB52 yields a characteristic Raman spectrum (Fig. 11e) with an intense doublet at 1303 and $1358 \mathrm{~cm}^{-1}$ and weaker bands at 483, 712 and $1251 \mathrm{~cm}^{-1}$ [40]. Kandinsky used four different mixtures for the green and bluish green areas. 

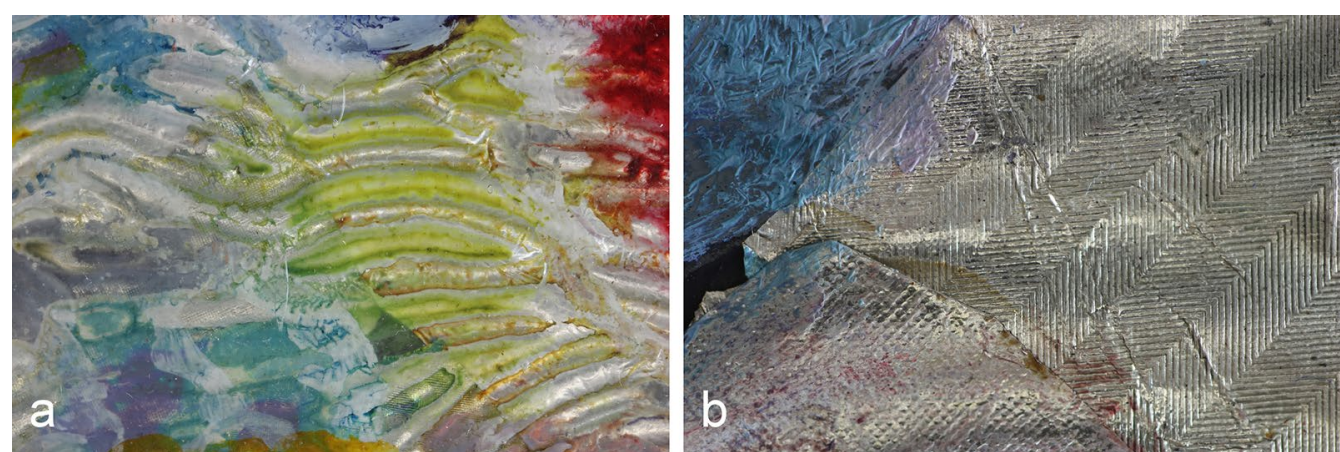

Fig. 10 Detailed photographs of the metal foils of Rudern: $\mathbf{a}$ front side, $\mathbf{b}$ reverse side. OSimone Bretz
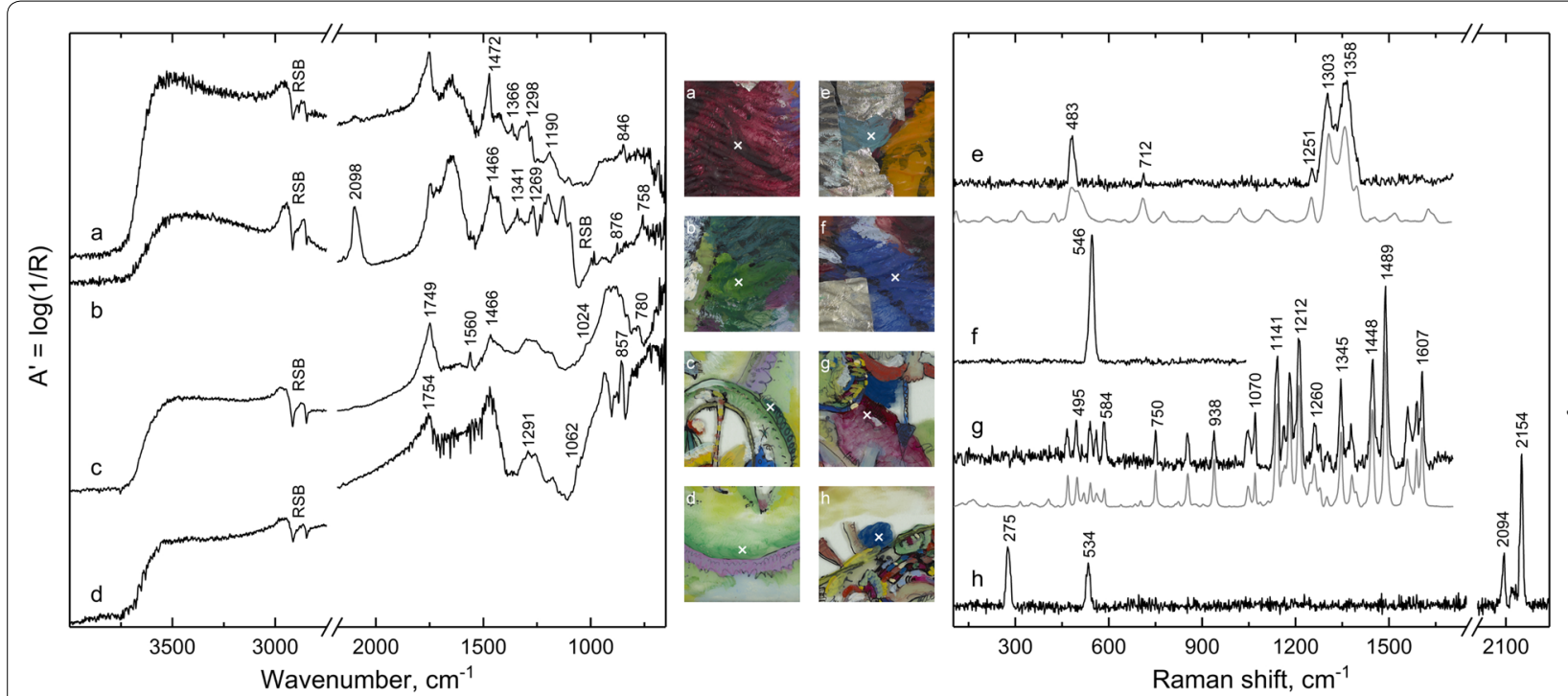

Fig. 11 DRIFTS (a-d) and Raman spectra (e-h) of Rudern (a, b; e, f) and Apokalyptischer Reiter II (c, d; g, h) along with detailed photos of the measured areas; offset was applied for better comparison. DRIFT spectra originate from the following spots: a) the red area of Fig. 3c (spot 5), b) the green area of Fig. 3c (spot 4), c) the bluish green area of Fig. $6 \mathrm{c}$ (spot 3) and d) the green area of Fig. 6c (spot 5); RSB= reststrahlen band. Raman spectra originate from the following spots: e) the greenish blue area of Fig. $3 c$ (spot 1), f) the blue area of Fig. 3c (spot 3), g) the pinkish red area of Fig. 6c (spot 2) and h) the blue area of Fig. 6c (spot 1). Reference spectra (grey lines): cf. [40]; $x=$ measured spots

Both viridian and Prussian blue were mixed with strontium yellow to obtain bluish green hues. Mixtures of an unknown yellow SOP with either Prussian blue or PB52 were found in the light green areas (e.g. Fig. 2c, spot 4). The Raman spectra of these areas were covered by extensive fluorescence, whereas the DRIFT spectrum reveals several bands at $758,876,996,1160,1235,1269$, 1341 and $1466 \mathrm{~cm}^{-1}$ that can be ascribed to the yellow SOP (Fig. 11b). Please note that the $\sim 1000-1150 \mathrm{~cm}^{-1}$ range is covered by the structured reststrahlen band (minimum at $1064 \mathrm{~cm}^{-1} ; \mathrm{SO}_{4}$ asymmetric stretching) of barium sulfate [41]. Due to this extensive band overlapping, an exact identification of the SOP was not successful. Additionally, the strong IR absorption band of
Prussian blue is visible at $2098 \mathrm{~cm}^{-1}$. Strontium yellow and cadmium yellow were identified in the yellow and dark yellow areas respectively. The DRIFT spectrum of the cadmium yellow, as in Allerheiligen II, shows characteristic signals of cadmium carbonate (sharp, inverted band with a minimum at $855 \mathrm{~cm}^{-1}$ ) (Fig. 9b). An alizarin-based red was found in the red areas, yielding typical bands at 846, 1190, 1276, 1298, 1351, 1366 and $1472 \mathrm{~cm}^{-1}$ in the DRIFT spectrum (Fig. 11a) [7, 9]. It needs to be emphasised that a clear discrimination between PR83 (synthetic alizarin) and natural madder lake is not possible with this method, but we would rather assume PR83 in the 1910s than its natural analogue. A mixture of PR83 and ultramarine blue 
was identified in the bluish violet area. Drying oil was classified as the binding media; however, a correct classification was sometimes hampered by extensive band overlapping in the DRIFT spectra. An unaffected spectrum is given in Fig. 9b, showing intense bands at 1466 and $1753 \mathrm{~cm}^{-1}$ and inverted bands with minima at 2849 and $2916 \mathrm{~cm}^{-1}$, which classify drying oil properly [7, 8, 33].

The painting Apokalyptischer Reiter II (1914) reveals several unpainted areas (i.e. the glass substrate is visible) and thin paint layers (Fig. 4a-c). XRF measurement of the glass shows high amounts of calcium, potassium and silicon and weak peaks of manganese, iron, strontium and lead. Zinc white and small amounts of lead white were reported from every spot. Barium sulfate was found only in the red areas, associated with a SOP. Kandinsky used ultramarine blue and Prussian blue (Raman bands at 275, 543, 2094, 2154; Fig. 11h) for the blue areas. The presence of significant Co peaks in the XRF spectra of the greenish blue (body of the horse) and lilac areas (the oval form around the inner scene) (Fig. 4c) suggest the presence of cobalt blue (Co-metal oxides, variable composition). Viridian was found in most green areas, where it is mixed with strontium yellow. Viridian yields typical IR bands at 1062, 1259 and $1291 \mathrm{~cm}^{-1}$ (Fig. 11d), of which the latter two indicate chromium borate, a by-product of the production process [32]. Strontium yellow shows characteristic bands at 858,878 and $935 \mathrm{~cm}^{-1}$ in the DRIFT spectrum. XRF measurements of the bluish green areas (Fig. 4, spot 3) yield particularly high values for copper and arsenic, suggesting the presence of a $\mathrm{Cu}-\mathrm{As}$ green. Emerald green $\left(3 \mathrm{Cu}\left(\mathrm{AsO}_{2}\right)_{2} \cdot \mathrm{Cu}\left(\mathrm{CH}_{3} \mathrm{COO}\right)_{2}\right)$ was identified by means of DRIFTS, showing typical bands at 780, 1024 ( $\mathrm{CH}$ bending), 1466 (COO symmetric stretching) and 1560 (COO antisymmetric stretching) in the spectrum (Fig. 11c) [42]. Moreover, a combination of both greens can be observed in some areas. Kandinsky used cadmium yellow, sometimes mixed with minor amounts of strontium yellow, for the yellow hues. Cadmium carbonate was not present in any DRIFT spectrum of these areas (Fig. 9a). Cinnabar and the red SOP PR60 were found in the red and pinkish red areas (Fig. 4c spot 2) respectively. PR60 yielded a high number of intense Raman bands, which are in good agreement with the reference spectrum (Fig. 11g) [40]. PR60 was mixed with cobalt blue to create the lilac hue of the oval form around the inner scene. Drying oil was classified in all spectra, and a typical spectrum is given in Fig. 9a. Bands at 1466, 1747, 2856 and $2943 \mathrm{~cm}^{-1}$ can be ascribed to the oily binder, whereas the small spectral features at 1321 and $1365 \mathrm{~cm}^{-1}$ originate from oxalates [39].

\section{Discussion}

\section{Pigments}

A direct comparison of the pigments used in the paintings is given in Table 1 . The results reveal specific differences in the palettes, but the following observations are valid for all the paintings: (1) zinc white is dominant among the white pigments, whereas lead white appears only in minor amounts and fillers were scarcely detected; (2) Prussian blue and ultramarine blue were mainly used for the blue areas and both were mixed with various reds to obtain violet hues, whereas only Prussian blue was mixed with various yellows for green hues; (3) Kandinsky particularly used strontium yellow and cadmium yellow for yellow areas; (4) violet pigments are absent; here these hues are always mixtures of blues and reds; and (5) viridian mixed with strontium yellow is the most common green in the paintings. Kandinsky used up to four different mixtures for green hues in one painting, but only one mixed green is reported from Allerheiligen II, where he varied the ratio of Prussian blue and strontium yellow (with minor amounts of cadmium yellow) to obtain green to bluish green hues (Fig. 5a-c).

Kandinsky's choices of materials evolved with his painting style throughout his career, as several technical examinations suggest [e.g. 20, 43-46]. Unpublished reports by the Doerner Institut and several technical studies [4446] of paintings between 1901 and 1913 allow a comparison of the used pigments with the presented results of our study. Generally, the previously reported results are consistent with our observations: zinc white is the dominant white pigment; Prussian blue and cadmium yellow are the most common blue and yellow pigments, respectively; cinnabar, Naples yellow, strontium yellow, chrome yellow and yellow ochre were also found in some paintings; viridian was mostly used for green areas, and violet pigments are completely absent. Additionally, unpublished results of Kandinsky's Munich palette from 1910/11 reveal the presence of cobalt blue, viridian, cinnabar, cadmium yellow, chrome yellow, bone black, zinc white and a synthetic red lake (unpublished report, Doerner Institut). Certain differences need to be emphasized when comparing them with the results of the four reverse glass paintings. Several proofs of PR3 in paintings from 1910 and of cadmium red in a painting of 1913 indicate an early use of these pigments by Kandinsky [44, 46], but both reds are absent in our study and in the Munich palette. The identification of emerald green in Apokalyptischer Reiter II proves that Kandinsky must have used this pigment also in his Munich period and not only in his later paintings [43].

McMilian et al. investigated a cardboard painting (1930) and four canvas paintings (1938-1941) and explored Kandinsky's use of Ripolin colours, a French 
brand of oleoresinous enamel paint [43]. The results show that mainly emerald green and viridian, sometimes mixed with cadmium yellow, Prussian blue or cerulean blue, were used for the green hues in these paintings. Cadmium yellow appears in four paintings, whereas strontium yellow is completely absent. Prussian blue, ultramarine blue and cobalt-based blues were identified as blue pigments. Moreover, the authors reported cobalt violets (Co-arsenate in one painting, Co-phosphate in three paintings) from the violet areas. Some organic yellow and red pigments were found in two paintings, but a closer identification was not possible with the methods applied. Microscopic investigation of several paint samples confirmed that Kandinsky mixed tube paints with dry pigment powders and other tube paints before applying them [43]. Generally, the palette reveals significant differences from the pigments identified in our study: (1) strontium yellow is absent; (2) cobalt violets were used instead of mixing red and blue paints; and (3) titanium white (production started 1909/10 [47]) is present in three paintings along with zinc white, lead white, barium sulfate and chalk.

The use of synthetic organic pigments in two paintings needs to be further emphasised. PR83 (synthetic alizarin; CI 58000:1) and anthraquinone lake PB52 (CI 63000) were reported in Rudern. PR83 is a common SOP and can be considered as part of the standard palette of artists at that time. It has often been reported in various artworks and 20th-century reverse glass paintings [e.g. 7, $9,48]$. PB52 is formed by combining an acidic (Alizarin Saphirol B, CI 63010) and a basic dye (Methylene Blue, CI 52015) [49] and was previously identified in a product palette for artists' colours made by Farbenfabriken vorm. Friedr. Bayer \& Co (1924) [50]. No further information on this pigment is available, and to the best of our knowledge only one proof of it in an artwork has been reported so far: Stege et al. found PB52 in the painting Masken auf der Strasse (1910) by Ernst L. Kirchner [51]. Its unspectacular greenish blue hue and its limited use in the painting could indicate that this colour was not so important for Kandinsky and that the pigment could be a cheap replacement product for a more expensive inorganic blue. This situation is well known for cinnabar, which was often replaced by PR3 at that time. Moreover, the naphthalene sulfonic acid pigment lake PR60 (CI 16105) was identified in Apokalyptischer Reiter II. It was mentioned as a pigment among the Mussini resin-oil colours ( $\mathrm{H}$. Schmincke \& Co. GmbH \& Co. KG), where it was used at least until 1922 [48]. It was also found in two Eilido colour charts (Pelikan/Wagner) from 1912 and 1926/38, which further indicates its use as artists' colours [52]. PR60 was reported in several paintings by Ernst L. Kirchner between 1913 and 1926 and in a lithographic ink of a printed poster from 1919 [51, 53]. Kandinsky painted large areas of Apokalyptischer Reiter II with PR60, revealing a characteristic, intense scarlet red hue (Fig. 4) that is unattainable with inorganic colourants. Hence, in contrast to PB52 (Rudern), Kandinsky very probably used PR60 intentionally, and it played a major role in the composition of Apokalyptischer Reiter II.

Another important aspect of reverse glass paintings is the use of metal foils (cf. Rudern; Fig. 10), as they enhance the gloss and create a glittering effect when the painting is viewed in reflected light. Metal pigments (e.g. fine-grained bronze powder) were also reported in other early paintings by Kandinsky [20]. Moreover, such metal powders and a tin foil were found in some reverse glass paintings by Heinrich Campendonk, who joined the "Blaue Reiter" collective in 1911 [7, 54]. Tin foils were common packaging materials for cigarettes and chocolate bars in the 19th and early 20th centuries [55]. Historical references also recommend tin foils as a backing layer for reverse glass paintings $[55,56]$. Kandinsky not only used tin foils, but also, in Rudern, glossy and silvery aluminium foils. The first commercial aluminium foil was produced in Switzerland in 1910 and started to replace its more expensive tin counterpart [57]. Its first use in Switzerland and Germany was for wrapping chocolate bars [57].

The presence of cadmium carbonate in two paintings (Allerheiligen II, Rudern) was proven by DRIFTS (Fig. 9). The measured area of Rudern does not seem to show any colour change, whereas the area of Allerheiligen II reveals a significant browning (Fig. 5c, spot 4). Cadmium carbonate was reported in early 20th-century paintings by Henri Matisse, James Ensor, Pablo Picasso and Edvard Munch and is often accompanied by other Cd phases like sulfates, oxalates and chlorides [58-64]. Synchrotronbased spectroscopic methods applied on the microscale have allowed researchers to reveal the distribution of various cadmium compounds and confirm that cadmium carbonate can occur as a photo-degradation product of cadmium yellow and as a remnant of the production process $[55,56]$. It was not only used as a starting agent for cadmium yellow synthesis $[47,65]$ but was also added as a lightener to the pigment powder [66]. However, the source of $\mathrm{CdCO}_{3}$ in the study presented here cannot be determined, and further investigations are needed to answer this question. Please note that cadmium carbonate is absent in Apokalyptischer Reiter II (Fig. 9a), although Kandinsky used cadmium yellow for the yellow areas. Reasons for this observation cannot be proven with the data available, and the following hypotheses need further investigations to be validated: (1) the paintings are all dated in a narrow timespan of 1911-14, which may be too short to see differences in alteration of the 
same substance (i.e. when the preservation conditions have been equal for all paintings); (2) Kandinsky worked with painting materials from different brands and companies throughout his career, hence it is likely that he did not used the same cadmium yellow in 1911 and 1914; (3) it needs also to be considered that one brand may also include the same pigment in different pigment qualities; and (4) other paintings (canvas, watercolour) from the same time should be further investigated to reveal if cadmium carbonate and/or degraded cadmium yellow occur to a larger extent.

\section{Binding media}

Barnett [67] described the painting technique of the investigated works of art as tempera (Auferstehung), tempera and china ink (Apokalyptischer Reiter II) and tempera and oil (Allerheiligen II; Rudern). It cannot be determined if this classification is based on inspections of the front or of the reverse side. Our visual inspection of the reverse side of the paintings suggests oil-based binders for Auferstehung, Rudern and Apokalyptischer Reiter II rather than tempera, indicated by the slightly pastose, glossy and wet-in-wet application of the paint. China ink can be found in Allerheiligen II, Rudern and Apokalyptischer Reiter II and shows the typical craquelure pattern. Allerheiligen II displays differences in the visual appearance of the painted areas ranging from glossy to matt (Fig. 7). This suggests the use of tempera and oil-based paints and confirms the description of Barnett [67].

Kandinsky mentions that he divides his artworks between oil and watercolour paintings, although he states that he also used different materials (tempera, gouache, watercolour, oil) in both categories [68 and references therein]. Personal notes on the binding media systems of his reverse glass paintings are not known, but Roethel [69] mentions that Kandinsky was not yet using glass as a special kind of surface, as the character of brush strokes is in no way different from that used on canvas. Tempera paints can be roughly described as water-thinnable paints (e.g. egg) or as a system with a continuous aqueous phase (e.g. oil in a water emulsion of egg yolk and linseed oil), but the exact definition may vary distinctively for different artists and periods [68]. Around 1900, Kandinsky conducted many experiments with tempera, as several handwritten recipes prove. For all mixtures marked "tempera", he used egg yolk and various water-soluble (e.g. casein, gum arabic) and -insoluble components (e.g. mastic, wax, copal, Canada balsam) [70]. Several of his historical tube paints (tempera and oil paints) are preserved, but many of them cannot be exactly dated [71]. In Germany, the earliest reference to commercially available, tempera-based tube paints dates from the 1870s [68]. Analysis of the binders of nine paints from Kandinsky's
Munich palette (1910/11) identified beeswax, drying oil, egg yolk and resins as major and polysaccharides (e.g. gum arabic) as minor components, but all the paints are mixtures with at least two binders [70]. The results suggest that Kandinsky used tube paints, which he modified sometimes by adding other components (mainly beeswax in turpentine) to adjust the texture, drying time and gloss of the paint [70]. The results of the four paintings in our study classify drying oil as the main binder. Only the DRIFT spectrum of the orange area of Allerheiligen II gave a hint at the presence of proteins as the watersoluble part of a tempera. The matte appearance (Fig. 7b) further suggests a different binding media system for that specific orange area. Generally, the structure (i.e. brush stroke, pastosity) and gloss of the painted surface do not play an important role for reverse glass paintings. That might be why Kandinsky used mainly oil-based colours for these paintings. Furthermore, oily binders provide the best adhesion properties for the smooth, non-porous glass surface. It is likely that Kandinsky preferred the oily binder to create more durable paintings rather than creating complex paint surfaces with different appearances using tempera mixtures. The four paintings show a good state of preservation, indicating a skilful use of materials.

We want to emphasize that DRIFTS may not be sensitive enough to detect small amounts of other binders, which could be also present in the other paintings. Please note that a mixture of one-part egg yolk and one-part oil (i.e. maximum oil content for egg tempera) would yield a dry paint with $\sim 90 \%$ lipids and only $\sim 10 \%$ proteins after evaporation of the water [72]. Furthermore, DRIFTS is restricted to the surface and cannot probe underlying paint layers. Advanced analyses (e.g. GC-MS), including micro-samples, are needed to get more precise information on the binders used in these paintings. Therefore, although it cannot be excluded that some of the studied paints are tempera paints, it seems rather likely that they are indeed oil paints.

\section{Conclusion}

The results show clearly the great importance of this technique in Kandinsky's oeuvre, as he not only used it in Murnau between 1909 and 1914, but also continued with it later in Moscow and Paris. Kandinsky presented several of his reverse glass paintings in exhibitions together with paintings on canvas and cardboard (e.g. "Der Blaue Reiter" exhibition, 1911), implying a coequal importance of these techniques [11]. He found inspiration in folkloristic Bavarian reverse glass paintings from the 19th- century and adapted his paintings with their characteristic features like black-painted backboards and painted frames or their stylistic features like twodimensional areas of unbroken colour, simplification of 
the forms, reduction of the colouration and dominance of the line. The use of corrugated glass and cathedral glass, however, could be evidence that Kandinsky wanted to distance himself from the folkloristic tradition of reverse glass painting [20]. The presented analytical results of the four reverse glass paintings reveal a broad palette of materials. Kandinsky painted not only with inorganic pigments, but also with synthetic organic pigments. For the scarlet red pigment PR60 in Rudern, a deliberate choice of this specific pigment seems likely, despite that time's ongoing debate on the fastness and stability of coal tar pigments in general. The application of metal foils is a specific feature of reverse glass paintings. The aluminium and tin foils in Rudern, which were both used originally as wrapping material, create a glittering effect that can be interpreted as light reflections on the water. Further research on Kandinsky's reverse glass paintings from different periods is needed to compare the palettes and may define certain mixtures as specific for this technique. Moreover, advanced analyses of binding media (e.g. GCMS), including micro-sampling, would give precise information also on the minor binding media components.

\section{Authors' contributions}

SS conducted the measurements and was responsible for most of the writing of the manuscript. SS, HS and OH interpreted the data. DO and GG examined the iconography and the art historical context. SB, LF and IW investigated the painting and glass technique and made the photographs available. GG managed the research project. All authors contributed to the discussion of the results and reviewed the manuscript. All authors read and approved the final manuscript.

\section{Author details \\ ${ }^{1}$ Federal Institute for Materials Research and Testing (BAM), Division 4.5, Unter den Eichen 44-46, Berlin, Germany. ${ }^{2}$ Museum Penzberg-Sammlung Campendonk, Am Museum 1, Penzberg, Germany. ${ }^{3}$ Institute of Art History, LMU Munich, Zentnerstraße 31, Munich, Germany. ${ }^{4}$ Conservator for Reverse Paintings on Glass, Garmisch-Partenkirchen, Germany. ${ }^{5}$ Städtische Galerie im Lenbachhaus und Kunstbau München, Luisenstraße 33, Munich, Germany. ${ }^{6}$ Doerner Institut, Bayerische Staatsgemäldesammlungen, Barer Str. 29, Munich, Germany. ${ }^{7}$ Centre for the Study of Manuscript Cultures, University of Hamburg, Warburgstraße 26, Hamburg, Germany.}

\section{Acknowledgements}

The authors would like to thank Patrick Dietemann for helpful comments on the binding media section and Olivier Bonnerot for fruitful discussions.

\section{Competing interests}

The authors declare that they have no competing interests.

\section{Availability of data and materials}

The datasets used and/or analysed in this study are available from the corresponding author on reasonable request.

\section{Funding}

The project "Hinterglasmalerei als Technik der Klassischen Moderne 19051955 "is funded by the Volkswagen-Stiftung, Hannover "Forschung in Museen" reference 89921 .

\section{Publisher's Note}

Springer Nature remains neutral with regard to jurisdictional claims in published maps and institutional affiliations.
Received: 16 March 2019 Accepted: 25 April 2019

Published online: 07 May 2019

\section{References}

1. Bretz S, Baumer U, Stege H, von Miller J, von Kerssenbrock-Krosig D. A German house altar from the sixteenth-century: conservation and research of reverse paintings on glass. Stud Conserv. 2009;53(4):209-24.

2. Baumer U, Dietemann P, Koller J. Identification of resinous materials on 16th and 17th-century reverse-glass objects by gas chromatography/ mass spectrometry. Int J Mass Spectrom. 2009;284:131-41.

3. Baumer U, Dietemann P. Identification and differentiation of dragon's blood in works of art using gas chromatography/mass spectrometry. Anal Bioanal Chem. 2010;397:1363-76.

4. Baumer U, Fiedler I, Bretz S, Ranz HJ, Dietemann P. Decorative reversepainted glass objects fromthe fourteenth to twentieth centuries: an overview of the binding media. Stud Conserv. 2012;57(sup1):9-18. https ://doi.org/10.1179/2047058412Y.0000000034.

5. Hahn O, Bretz S, Hagnau C, Ranz HJ, WolffT. Pigments, dyes, and black enamel-the colorants of reverse paintings on glass. Archaeol Anthrop Sci. 2009;1:263-71.

6. Mollica Nardo V, Renda V, Anastasio G, Caponetti E, Saladino ML, Vasi CS, Ponterio RC. A combination of portable non-invasive techniques to study on reverse glass paintings at Mistretta museum. Microchem J. 2019;146:640-4.

7. Steger S, Stege H, Bretz S, Hahn O. Capabilities and limitations of handheld diffuse reflectance infrared fourier transform spectroscopy (DRIFTS) for the analysis of colourants and binders in 20th-century reverse paintings on glass. Spectrochim Acta A. 2018;195:103-12.

8. Steger S, Bretz S, Stege H, Hahn O. Methodological approach for in situ spectroscopic analysis of modern reverse paintings on glass: a case study of Kreuzabnahme (1914/15) —an outstanding example by Carlo Mense. Eur Phys J Plus. 2019. https://doi.org/10.1140/epjp/i2019-12549-6.

9. Steger S, Stege H, Bretz S, Hahn O. A complementary spectroscopic approach for the non-invasive in situ identification of synthetic organic pigments in modern reverse paintings on glass (1913-1946). J Cult Herit. 2019. https://doi.org/10.1016/j.culher.2019.01.011.

10. Steger S, Oesterle D, Mayer R, Hahn O, Bretz S, Geiger G. First insights into Chinese reverse glass paintings gained by non-invasive spectroscopic analysis-tracing a cultural dialogue. Archaeol Anthrop Sci. 2019. https:// doi.org/10.1007/s12520-019-00799-3.

11. Roethel HK. Gabriele Münter: 1877-1962. Ausstellung vom 13. Okt. bis 2. Dez. 1962, Städt. Galerie im Lenbachhaus, München. [exhibition catalogue]. Munich: Städt. Galerie im Lenbachhaus; 1962 (in German).

12. Hoberg A. Gabriele Münter in München und Murnau 1901-1912. In: Hoberg A, Friedel H, editors. Gabriele Münter 1877-1962. Retrospektive. Munich: Prestel; 1992. p. 27-46 (in German).

13. Gockerell N. Hinterglasbilder, Schnitzereien und Holzspielzeug von Gabriele Münter gesammelt, kopiert und in ihren Werken dargestellt. Munich: Prestel; 2000 (in German).

14. Dütsch I. ... daß die Glasbilder nicht aussterben..."Neue Erkenntnisse zur Geschichte der Murnauer Hinterglasmalerei In: Bayerisches Jahrbuch für Volkskunde. Munich; 2002. p. 81-102. (in German).

15. Vail KPB. Die Werke. In: Friedel H, editor. Kandinsky—Absolut. Abstrakt. Munich: Prestel; 2008. p. 50 (in German).

16. Der Salmen B. Der Almanach „Der Blaue Reiter". Bilder und Bildwerke in Originalen. Murnau: Schloßmuseum Murnau; 1998 (in German).

17. Hoberg A. assily Kandinsky_Absolut. Abstrakt. Konkret. In: Friedel H, editor. Kandinsky -Absolut. Abstrakt. Munich: Prestel; 2008. p. 190-225 (in German).

18. Zweite A. Kandinsky und München, Begegnungen und Wandlungen 1896-1914. Munich: Prestel; 1982.

19. Roethel HK, Benjamin JK. Kandinsky. Werkverzeichnis der Ölgemälde: 1900-1915, vol. 1. Munich: C.H. Beck Verlag; 1982 (in German).

20. Wackernagel RH. "Bei,Öl'auch Aquarell..., bei,Aquarell'auch Öl usw.,' Zu Kandinskys Ateliers und seinen Maltechniken. In: Friedel H, editor. Das Bunte Leben. Wassily Kandinsky im Lenbachhaus. Cologne: DuMont; 1995. p. 547-67 (in German).

21. Winkelmeyer I. El cosmos de color de Kandinsky Tecnologia artistica de los años 1896 a 1914. In: Fernández Félix M, editor. Kandinsky, pequeños 
mundos. Instituto Nacional de Bellas Artes/Museo del Palacio de Bellas Artes: México; 2018. p. 174-99 (in Spanish).

22. Bretz S. Hinterglasmalerei, die Farben leuchten so klar und rein. Maltechnik, Geschichte, Restaurierung. Munich: Klinkhardt \& Biermann; 2013 (in German).

23. Cable M. The development of flat glass manufacturing processes. Trans Newcomen Soc. 2004;74:19-43.

24. Otero V, Campos MF, Pinto JV, Vilarigues M, Carlyle L, Melo MJ. Barium, zinc and strontium yellows in late 19th- early 20th-century oil paintings. Herit Sci. 2017;5:46.

25. Hakeem MA, Jackson DE, Hamlin JJ, Errandonea D, Proctor JE, Bettinelli M. High pressure raman, optical absorption, and resistivity study of $\mathrm{SrCrO}_{4}$. Inorg Chem. 2018;57:7550-7.

26. Monico L, Janssens K, Hendriks E, Brunetti BG, Miliani C. Raman study of different crystalline forms of $\mathrm{PbCrO}_{4}$ and $\mathrm{PbCr}_{1-x} \mathrm{~S}_{x} \mathrm{O}_{4}$ solid solutions for the noninvasive identification of chrome yellows in paintings: a focus on works by Vincent van Gogh. J Raman Spectrosc. 2014;45:1034-45.

27. Barsan MM, Butler IS, Fitzpatrick J, Gilson DFR. High pressure studies of the micro-raman spectra of iron cyanide complexes: prussian blue $\left(\mathrm{Fe}_{4}\left[\mathrm{Fe}(\mathrm{CN})_{6}\right]_{3}\right)$, potassium ferricyanide $\left(\mathrm{K}_{3}\left[\mathrm{Fe}(\mathrm{CN})_{6}\right]\right)$, and sodium nitroprusside $\left(\mathrm{Na}_{2}\left[\mathrm{Fe}(\mathrm{CN})_{5}(\mathrm{NO})\right] \cdot 2 \mathrm{H}_{2} \mathrm{O}\right)$. J Raman Spectrosc. 2011;42:1820-4.

28. Samain L, Grandjean F, Long GJ, Martinetto P, Bordet P, Strivay D. Relationship between the synthesis of prussian blue pigments, their color physical properties, and their behavior in paint layers. J Phys Chem C. 2013;117:9693-712

29. Silva CE, Siva LP, Edwards HGM, De Oliveira LFC. Diffuse reflection FTIR spectral database of dyes and pigments. Anal Bioanal Chem. 2006;386:2183-9.

30. Vetter W, Schreiner M. Characterization of pigment-binding media systems comparison of non-invasive in situ reflection FTIR with transmission FTIR microscopy. ePS. 2011;8:10-22.

31. Miliani C, Rosi F, Borgia I, Benedetti P, Brunetti BG, Sgamellotti A. Fiber-optic fourier transform mid-infrared reflectance spectroscopy: a suitable technique for in situ studies of mural paintings. Appl Spectrosc. 2007:61(3):293-9.

32. Zumbuehl S, Scherrer NC, Berger A, Eggenberger U. Early viridian pigment composition characterization of a (hydrated) chromium oxide borate pigment. Stud Conserv. 2009;54:149-59.

33. Invernizzi C, Daveri A, Vagnini M, Malagodi M. Non-invasive identification of organic materials in historical stringed musical instruments by reflection infrared spectroscopy: a methodological approach. Anal Bioanal Chem. 2017:409:3281-8

34. Frost RL, Martens WN, Kloprogge T. Raman spectroscopic study of cinnabar $(\mathrm{HgS})$, realgar $\left(\mathrm{As}_{4} \mathrm{~S}_{4}\right)$, and orpiment $\left(\mathrm{As}_{2} \mathrm{~S}_{3}\right)$ at 298 and $77 \mathrm{~K}$. Neues JB Miner Monat. 2002;10:469-80.

35. Desnica V, Furic K, Schreiner M. Multianalytical characterization of a variety of ultramarine pigments. ePS. 2004;1:15-21.

36. Caggiani MC, Cosentino A, Mangone A. Pigments checker version 3.0, a handy set for conservation scientists: a free online Raman spectra database. Microchem J. 2016;129:123-32.

37. Ashoka S, Nagaraju G, Thipperudraiah KV, Chandrappa GT. Controlled synthesis of cadmium carbonate nanowires, nanoribbons, nanorings and sphere like architectures via hydrothermal method. Mater Res Bull. 2010;45:1736-40.

38. Ashoka S, Chithaiah P, Chandrappa GT. Studies on the synthesis of $\mathrm{CdCO}_{3}$ nanowires and porous CdO powder. Mater Lett. 2010;64:173-6.

39. Monico L, Rosi F, Miliani C, Daveri A, Brunetti BG. Non-invasive identification of metal-oxalate complexes on polychrome artwork surfaces by reflection mid-infrared spectroscopy. Spectrochim Acta A. 2013;116:270-80.

40. Fremout W, Saverwyns S. Identification of synthetic organic pigments: the role of a comprehensive digital Raman spectral library. J Raman Spectrosc. 2012;43:1536-44.

41. Miliani C, Rosi F, Daveri F, Brunetti BG. Reflection infrared spectroscopy for the non-invasive in situ study of artists' pigments. Appl Phys A Mater. 2012;106:295-307.

42. Buti D, Rosi F, Brunetti BG, Miliani C. In-situ identification of copper-based green pigments. Anal Bioanal Chem. 2013;405:2699-711.

43. McMillan G, Casadio F, Fiedler I, Sorano-Stedman V. An investigation into Kandinsky's use of Ripolin in his paintings after 1930. J Am Inst Conserv. 2013;52(4):258-77.
44. Steele E, McMillan G, Khandekar N, Mysak E. Side by side: the technical investigation of sketch I for painting with white border and painting with white border. In: Smithgall E, editor. Kandinsky and the harmony of silence: painting with white border. Washington D.C: Yale University Press; 2011. p. 106-21.

45. McMillan G, Kowalski V. Kandinsky's materials and techniques: a preliminary study of five paintings. In: Bashkoff T, editor. Kandinsky (exhibition catalogue). New York: Solomon R. Guggenheim Foundation; 2009. p. $121-3$.

46. Zumbühl S, Gross M. Alexej von Jawlensky, Wassily Kandinsky - Eine Künstlerfreundschaft aus materialtechnologischer Sicht, Reihe Bild und Wissenschaft - Forschungsbeiträge zu Leben und Werk Alexej von Jawlenskys, vol. 3. Locarno: Alexej von Jawlensky Archiv; 2009. p. 256-63.

47. Mayer R. The artist's handbook of materials and techniques. New York: Viking Press; 1991.

48. Fux A. Zur Verwendung synthetisch organischer Pigmente in der Kunst des 20. Jahrhunderts. MA-Thesis, Hochschule der Künste Bern, 2013. (in German).

49. Venkataraman K. The Chemistry of Synthetic Dyes, vol. 5. London: Academic Press; 1971.

50. Schäning A. Synthetische organische Farbmittel aus einer technologischen Materialsammlung des 19./20. Jahrhunderts: Identifizierung, Klassifizierung und ihre Verwendung sowie Akzeptanz in (Künstler)Farben Anfang des 20. Jahrhunderts. Ph.D.-thesis, Akademie der Bildenden Künste Wien; 2010. (in German).

51. Stege H, Richter M, Steuer C. Indanthrenblau, Helioechtrot and Pigmentscharlach-identification of synthetic organic pigments in paintings of Ernst Ludwig Kirchner using Raman microscopy. ZKK J Art Technol Conserv. 2013;27(1):30-42.

52. Skowranek H, Stege H, Krekel C, Steuer C. Eilido colours. Sources relating to the introduction of coal-tar colours and their controversial reception in the early 20th-century. In: Eyb-Green S, Townsend JH, Pilz K, Kroustallis S, van Leeuwen I, editors. Sources on art technology: back to basics. London: Archetype Publications; 2016. p. 34-42.

53. Centeno S, Buisan VL, Ropret P. Raman study of synthetic organic pigments and dyes in early lithographic inks (1890-1920). J Raman Spectrosc. 2006;37:1111-8.

54. Geiger G, Bretz S. Heinrich Campendonk, Die Hinterglasbilder. Cologne: Wienand; 2017 (in German).

55. Freytag O. Hinterglasmalerei: Ihre künstlerische Eigenart und Arbeitsweise in Vergangenheit und Gegenwart. Ravensburg: Otto Maier Verlag; 1937 (in German).

56. Wessels E. Die Hinterglasmalerei: Anleitungen zur Herstellung von Malereien hinter ober unter Glas, sowie Glasmalerei-Imitation, GlasVergoldung und dergleichen. Esslingen: Neff; 1913 (in German).

57. Skrabec QR. Aluminum in America: a history. Jefferson: McFarland; 2016.

58. Van der Snickt G, Dik J, Cotte M, Janssens K, Jaroszewicz J, De NolfW, Groenewegen J, Van der Loef $L$. Characterization of a degraded cadmium yellow (CdS) pigment in an oil painting by means of synchrotron radiation based X-ray techniques. Anal Chem. 2009;81(7):2600-10.

59. Topalova-Casadiego B, Plahter U. The Scream by Edvard Munch: painting techniques and colouring materials. In: Spring M editor. Studying old master paintings technology and practice The national gallery technical bulletin 30th anniversary Conference postprints. London: Archetype; 2011. p. 244-252.

60. Pouyet E, Cotte M, Fayard B, Salomé M, Meirer F, Mehta A, Uffelman ES, Hull A, Vanmeert F, Kieffer J, Burghammer M, Janssens K, Sette F, Mass J. 2D X-ray and FTIR micro-analysis of the degradation of cadmium yellow pigment in paintings of Henri Matisse. Appl Phys A Mater. 2015;121:967-80

61. Mass JL, Opila R, Buckley B, Cotte M, Church J, Mehta A. The photodegradation of cadmium yellow paints in Henri Matisse's Le Bonheur de vivre (1905-1906). Appl Phys A Mater. 2013;111:59-68.

62. Mass J, Sedlmair J, Schmidt Patterson C, Carson D, Buckley B, Hirschmugl C. SR-FTIR imaging of the altered cadmium sulphide yellow paints in Henri Matisse's Le Bonheur de vivre (1905-6) _examination of visually distinct degradation regions. Analyst. 2013;138(20):6032-43.

63. Miliani C, Monico L, Melo MJ, Fantacci S, Angelin EM, Romani A, Janssens K. Photochemistry of artists dyes and pigments: towards better understanding and prevention of colour change in works of art. Angew Chem Int Ed. 2018;57:7324-34. 
64. Comelli D, MacLennan D, Ghirardello M, Phenix A, Schmidt Patterson C, Khanjian H, Gross M, Valentini G, Trentelman K, Nevin A. Degradation of cadmium yellow paint: new evidence from photoluminescence studies of trap States in Picasso's Femme (Époque des "Demoiselles d'Avignon"). Anal Chem. 2019;1:1. https://doi.org/10.1021/acs.analchem.8b04914.

65. Ghirardello M, Mosca S, Marti-Rujas J, Nardo L, Burnstock A, Nevin A, et al. Time-resolved photoluminescence microscopy combined with X-ray analyses and raman spectroscopy sheds light on the imperfect synthesis of historical cadmium pigments. Anal Chem. 2018;90:10771-9.

66. Fiedler I, Bayard MA. Cadmium Yellows, Oranges and Reds. In: Feller RL, editor. Artists pigments: a handbook of their history and characteristics, vol. 1. London: Archetype Publications; 1986. p. 65-108.

67. Barnett VE. Katalog. In: Friedel H, editor. Das Bunte Leben. Wassily Kandinsky im Lenbachhaus. Cologne: DuMont; 1995. p. 570-653 (in German).

68. Neugebauer W. Von Böcklin bis Kandinsky Kunsttechnologische Forschungen zur Temperamalerei In München zwischen 1850 und 1914. Berlin: Pro Business digital; 2015 (in German).
69. Roethel HK. Vasily kandinsky: painting on glass (Hinterglasmalerei). New York: Solomon R. Guggenheim Foundation; 1966.

70. Wackernagel RH. "Ich werde die Leute... in Öl und Tempera beschwindeln,...". Neues zur Maltechnik Wassily Kandinskys. ZKK Zeitschrift für Kunsttechnologie und Konservierung. 1997;11(1):97-128. (with English translation, pp. 129-144). (in German).

71. Dagron B. Inventaire du matériel de l'atelier du peintre Vassily Kandinsky. Techne, la science au service de l'histoire de l'art et des civilisations. 1998;8:64-76 (in French).

72. Dietemann P, Neugebauer W, Lutz L, Beil C, Fiedler I, Baumer U. A colloidal description of tempera and oil paints, based on a case study of Arnold Böcklin's painting Villa am Meer II (1865). ePS. 2014;11:29-46.

\section{Submit your manuscript to a SpringerOpen ${ }^{\circ}$ journal and benefit from:}

- Convenient online submission

- Rigorous peer review

Open access: articles freely available online

- High visibility within the field

- Retaining the copyright to your article

Submit your next manuscript at $\boldsymbol{\nabla}$ springeropen.com 